\title{
Health indicators and contaminant levels of a critically endangered species in the Gironde estuary, the European sturgeon.
}

Marie-Laure Acolas ${ }^{1}$, Blandine Davail ${ }^{2 *}$, Patrice Gonzalez ${ }^{3}$, Séverine Jean ${ }^{4}$, Christelle Clérandeau ${ }^{2}$, Bénédicte Morin $^{2}$, Pierre-Yves Gourves ${ }^{3}$, Guillemine Daffe ${ }^{3}$, Pierre Labadie ${ }^{5}$, Annie Perrault ${ }^{4}$, Mathilde Lauzent ${ }^{5}$, Maud Pierre ${ }^{1}$, Romaric Le Barh ${ }^{1}$, Magalie Baudrimont ${ }^{3}$, Laurent Peluhet ${ }^{5}$, Karyn Le Menach ${ }^{5}$, Hélène Budzinski ${ }^{5}$, Eric Rochard ${ }^{1}$, Jérôme Cachot $^{2}$

1 Irstea, Research Unit EABX, Aquatic ecosystems and global change, 50 avenue de Verdun, 33612 Gazinet Cestas, France

2 University of Bordeaux, UMR 5805 EPOC, Aquatic Ecotoxicology, B2, allée Geofroy Saint-Hilaire, 33405 Talence France

3 University of Bordeaux, UMR 5805 EPOC, Aquatic Ecotoxicology, Place du Dr B. Peyneau, Arcachon, France

4 Laboratory of Fonctionnal Ecology and Environment (Ecolab), Ecotoxicology and Ecosystems, Campus ENSAT - Av de l'Agrobiopole - BP 32607, Auzeville-Tolosane, Caxtanet-Tolosan Cedex, France

5 University of Bordeaux, UMR 5805 EPOC, LPTC, $351 \mathrm{crs}$ de la Libération, 33405 Talence, France

(*) Corresponding author: Blandine.davail@u-bordeaux.fr

\section{Author Contributions:}

Notice that ML.A and B.D. contribute to equal part to this work

ML.A., B.D., B.M., P.G., H.B., S.J., E.R. and J.C. conceived and designed the experiments; All Authors contributed to the experiments; ML.A, B.D., S.J.,C.C, M.L., R,LB. did the samplings on fish onboard; B.D.,P-Y.G., G.D., A.P., M.L, L.P., K.LM., C.C. made the assays. ML.A, B.D., M.P., M.B, C.C. managed with the statistical analyzes of the data; ML.A and. B.D. wrote the paper. E.R. and J. C. supervised the SturTOP research project. Conflicts of Interest: The authors declare no conflict of interest.

\section{Abstract}

The European sturgeon, Acipenser sturio, is a highly endangered species that almost disappeared in the last decades. Thanks to yearly restocking of the population, this species is still found in the Gironde estuary (France), where juveniles grow during several years before leaving to the ocean. The aim of this study was to evaluate the pressure exerted on these fish by known organic and inorganic contaminants during their stay at the Gironde estuary, and to get information on the fish's health in this context. Monthly captures over the year 2014, provided 87 fish from the cohorts 2012 and 2013 mainly, and from cohorts 2008, 2009 and 2011, all fish born in hatchery. We report the very first analyses of contaminant levels and of biological markers measured in the blood of these fish. Low inorganic contamination was found, composed of seven metals mainly: $\mathrm{Zn}\left(<5 \mu \mathrm{g} \cdot \mathrm{mL}^{-1}\right), \mathrm{Fe}\left(<1.5 \mu \mathrm{g} \cdot \mathrm{mL}^{-1}\right), \mathrm{Cu}\left(<0.8 \mu \mathrm{g} \cdot \mathrm{mL}^{-}\right.$ $\left.{ }^{1}\right)$, Se $\left(<0.8 \mu \mathrm{g} \cdot \mathrm{mL}^{-1}\right)$, As $\left(<0.25 \mu \mathrm{g} \cdot \mathrm{mL}^{-1}\right)$, Co $\left(<0.14 \mu \mathrm{g} \cdot \mathrm{mL}^{-1}\right)$ and $\mathrm{Mn}\left(<0.03 \mu \mathrm{g} \cdot \mathrm{mL}^{-1}\right)$. Concerning persistent organic contaminants, the sum of 7 PCBs varied from 1 to $10 \mathrm{ng} . \mathrm{g}^{-1}$ plasma, that of 8 OCPs from 0.1 to $1 \mathrm{ng} \cdot \mathrm{g}^{-1}$, and that of 8 PBDEs from 10 to 100 pg.g ${ }^{-1}$. Higher levels of contaminants were measured during spring as compared to summer. The sex steroid hormone plasma levels (estradiol, testosterone and 11 ketotestosterone) were quite low, which 
was predictable for juveniles. The transcription of reproduction-involved genes ( $E s t R, A R, L H R$, sox 9 ) in blood cells was demonstrated for the first time. Some of them were correlated to organic contaminant levels PCBs and OCPs. Other gene transcriptions ( $\operatorname{sod} C u$ and bax) were correlated to PCBs and OCPs. However, the DNA damage level measured here as comet tail DNA and micronuclei ratio in red blood cells, were in the very low range of the values commonly obtained in fish from pristine areas. The data presented here can serve as a reference base for future monitoring of this population of sturgeons.

\section{Key words}

Sturgeon, estuary, sex steroid, gene transcription, genotoxicity, inorganic and organic contaminants.

\section{Short title}

Biomarkers and contaminant level in stocked European sturgeon

\section{Acknowledgments}

This study was funded by the Région Aquitaine, IRSTEA and the French National Research Agency (SturTOP research project $\mathrm{N}^{\circ}$ ANR-13-CESA-0018-01). It was carried out as part of the Cluster of Excellence COTE. Sampling campaigns were funded within the frame of the French National Action Plan in favor of A. sturio restoration by AdourGaronne water agency, Aquitaine region and Gironde general council in 2014. We wish to thank J.F. Bigot and B. Ballion (Irstea) for managing trawl fishing operation as well as J. Kordek (Irstea), F. Le Bihanic-Michel (EPOC) and M-A. Cornet (EPOC) who occasionally participate to the field sampling. 


\section{Introduction}

The Gironde estuary is a highly turbid estuary with a macrotidal regime with historical pollution mainly due to geology, former mining and ore treatment (Lanceleur et al. 2011) industrial waste (Budzinski et al. 1997; Grousset et al. 1999) and agricultural activities (Kraepiel et al. 1997; Masson et al. 2006) but also urban wastewaters (Deycard et al. 2017). In addition, the regular re-suspension of sediment and the salinity gradient can induce remobilization of contaminants (Lanceleur et al. 2013).

In parallel, the estuary fish assemblages reveal the presence of 75 fish species (Lobry et al. 2003) with 8 diadromous species regularly observed, the Gironde being a relatively good ecological reference among European estuaries. Levels of fish contamination were highly variable according to species and organs analyzed. Durrieu et al. (2005) studied 4 metals $(\mathrm{Cd}, \mathrm{Zn}, \mathrm{Cu}, \mathrm{Hg}$ ) in 4 organs (gills, muscle, liver and kidney) in eight species. Results highlighted low contamination levels for meagre Argyrosomus regius, seabass Dicentrarchus labrax, sole Solea solea, canary drum Umbrina canariensis but high levels for eel Anguilla anguilla, flounder Platichthys flesus and particularly mullet Liza ramada, those ones spending a longer journey in the estuary ( 3 to 14 years). In muscle tissue, metal concentration was relatively low except for $\mathrm{Hg}$ among twaite shad Alosa fallax. In kidneys and liver of L. ramada and A. Anguilla, $\mathrm{Cd}$ and $\mathrm{Cu}$ levels may imply structural and functional disturbances (Durrieu et al. 2005). Compared to other European estuaries (Seine, Mersey and Guadalquivir) the Cd concentration was higher in the Gironde estuary (Durrieu et al. 2005). A study on eels PBDE and PCB contamination (Tapie et al. 2011) indicated contamination increase during the ontogeny mainly through trophic ways. The highest contamination level concerned adult eels (silver eels) and was similar to Northern Europe contamination levels which raise sanitary problem for human consumption but also can affect eel sexual maturation. A study on PCB contamination in fish community from the Gironde estuary, confirmed the high concentration levels in eels and food web magnification (Bodin et al. 2014).

The European sturgeon, Acipenser sturio, was formerly widely caught in the Atlantic Ocean and in the rivers of the Western Europe. The wild population of European sturgeon showed a dramatic decline since the sixties (Castelnaud 2011) and was almost extincted by the nineties (Brosse 2003; Rochard et al. 2001). This species is nowadays no more captured than in the rivers Garonne and Dordogne in Southwest France. Classified as critically endangered by IUCN criteria, the species has benefited of a European action plan (Rosenthal et al. 2007) and of a French national action plan started in 2011 (MEDDTL 2011). Thanks to the constitution of a captive stock (Williot et al. 2011) a regular stocking program was enhanced for A. sturio restauration and the estuarine fraction of the sustained population was monitored again since 2009 (Acolas et al. 2011a, Acolas et al. in prep.). The success of a restoration program is highly dependent on the survival of larvae, young of the year and of juveniles in the environment. To ensure its success, warranty is needed that the suspected causes of decline are removed or largely attenuated. The monitoring of the pollutant levels in fish blood might be very informative of the pressure exerted by pollutants on wild fish population.

The only study dealing with contamination levels on a sturgeon species in the Gironde concerned the Siberian sturgeon A. baerii which is an exotic species incidentally released after the 1999 tempest (Acolas et al. 2018). Maury-Brachet et al. (2007) compared the level of metallic contamination (5 metals: $\mathrm{Cd}, \mathrm{Zn}, \mathrm{Cu}, \mathrm{Pb}, \mathrm{Hg}$ ) between escaped individuals 
recaptured and corresponding farmed fish in 4 organs (gills, muscle, liver, kidneys). The analysis revealed higher levels of $\mathrm{Cd}, \mathrm{Pb}$ and $\mathrm{Hg}$ in the fish collected in the estuary compared to the fish farm. However, the concentration in those fish, after 3 years spent in the estuary, was considered low compared to other Gironde species such as eels and mullets (Durrieu et al. 2005). The study concluded that taking in account their live in the same habitat and their diet with the same preys, the endangered species A. sturio was probably not exposed to a high risk of polymetallic contamination (Maury-Brachet et al. 2007). Organic contaminants and physiological indicators were not studied at that time.

Sturgeons are threatened throughout the world and many factors such as over-harvest, habitat loss or alteration and pollution were mentioned as causes to their decline (Billard and Lecointre 2001). Some studies on contamination in the wild were carried out but they mainly took place in rivers. Li et al. (2003) recorded a relatively low contamination of PCBs for lake sturgeon Acipenser fulvescens (but one individual only) in Detroit River compared to other fish species. For the same species, in the lower Niagara River, the levels of organochlorine pesticides were measured as well as sex steroids. The contamination levels were low and did not affect fish reproductive physiology (Jacobs et al. 2014). In San Francisco bay, white sturgeon (Acipenser transmontanus) exhibited intermediate contamination in PCBs, PBDE, $\mathrm{Hg}$ and Se (Greenfield et al. 2003) compared to the other fish species. Concentration of $\mathrm{Hg}$ was highly correlated to sturgeon length. PCBs concentrations were very variable according to years, probably in connection with movement and diet variations. Se contamination seemed to be linked to diet composed with bivalves (Greenfield et al. 2003). In the Columbia River, samplings carried out on white sturgeon suggest that organochlorine pollutants could have adverse effect on their reproductive physiology since effects on plasma androgen concentration were highlighted (Foster et al. 2001). The results of all those studies enhanced the necessity to assess, within the frame of a sturgeon population restauration measures, the possible impacts of the aquatic environment quality on fish health and their capacity to fulfil their life cycle.

Most of the studies on wild fish populations used a lethal sampling protocol, and only few studies applied low invasive methods of sampling (e.g. Baillon et al. 2016; Sturrock et al. 2013). But when studying critically endangered species, no sacrifice is allowed, the body integrity and health of the animal should be favored. Working on low impact biological sampling such as fin clip or blood sample is required. The impact of contaminants on fish health can be assessed through multiple biomarkers (Lagadic et al. 1997; Van der Oost et al. 2003). Comet and micronucleus assays are suitable indicators of genotoxicity (e.g. Braham et al. 2017; Hariri et al. 2018). To assess the impact of endocrinedisrupting contaminants, vitellogenin concentration or steroid hormones levels are successfully measured from blood plasma (e.g. Gundersen et al. 2008; Jacobs et al. 2014; Farkas et al. 2017). The analysis of target gene transcription can be performed on red blood cells, since they are nucleated at fish (Valton 2017).

The European sturgeon is an anadromous long-lived species. The juveniles spend several years in the Gironde estuary (Acolas et al. 2011b; Castelnaud et al. 1991), then they can be vulnerable to chronic contamination. In the present study, our objectives were to assess health indicators of the estuarine fraction of the European sturgeon sustained population with non-invasive biological samplings. On one hand, biomarkers of genome integrity such as comet and micronucleus assays were measured in blood cells. They were supplemented by the analysis of target genes transcriptions in blood cells. Some of the target genes were chosen in order to inform about the reproductive function 
in relation to the age of immature fish. Others were related to the detoxification and oxidative stress. On the other hand, the concentration of inorganic and organic contaminants and the sex steroid hormones levels, were measured, at the individual level in blood plasma.

The combine use of all those indicators to characterize the health status and the contamination fingerprint of an endangered fish population in its natural environment, through non-destructive samplings, is very rare. The data presented here can serve as a reference base for future monitoring of this population of sturgeons.

\section{Materials and methods}

\section{$\underline{\text { Study site, fish collection and fish characteristics }}$}

A. sturio reproduction occurs in freshwaters and juveniles migrate downstream to sea to achieve their growth .A particularity of this species is that juveniles spend a few years in the estuary (at least 2 years) before carrying out some back and forth movement between the estuary and the sea and finally leave the estuary (Castelnaud et al. 1991, Acolas et al. 2011b). Due to this particularity, monitoring during their stay in the estuary allow assessing some population indicators (Acolas et al. in prep.). Sampling was performed with a benthic trawl in areas where trawling is feasible (no ledge and outside of the navigation channel). All fish captured were processed before releasing them. Each sturgeon was individually marked with external and internal tags, measured and weighed, fin samples were taken for age determination and genetic monitoring. During the seven trawling campaigns that were carried out in year $2014,87 \mathrm{~A}$. sturio were caught and blood samples were taken from 68 among them to assess health parameters. For the purpose of this study, fish were given a number according to their date of capture, increasing from February to September 2014. Most fish (54\%) were captured during summer; they belonged to 6 cohorts according to age reading on a section of the pectoral fin ray (Rochard \& Jatteau, 1991) and genetic analysis (Roques et al. 2016). Most fish (72\%) were 2 years old (cohort 2012) (Figure 1). Fish fork length averaged $58 \mathrm{~cm} \pm 18(\min 35, \max 150 \mathrm{~cm})$ and weight averaged $1.5 \mathrm{~kg}$ $\pm 2.7(\min 200 \mathrm{~g}, \max 21.2 \mathrm{~kg})$.

Thanks to the stocking plan strategy and the genetic monitoring (Acolas et al. in prep.), we were able to assess, their age at release and the river they were released in. We then made 2 groups: fish released at or before 3 months old (larvae, larvae or 3 months old, 3 months old) which represented $85 \%$ of the capture and fish released older (1 or 2 years old) which have spent much time in captivity. Then, among one cohort, we could have fish which spent different time in captivity and then different time spent in the natural environment (Figure 2). Fish were released either in the Dordogne River or in the Garonne River, and in 2014, most fish recaptured in the estuary (70\%) were originated from the Garonne river. 


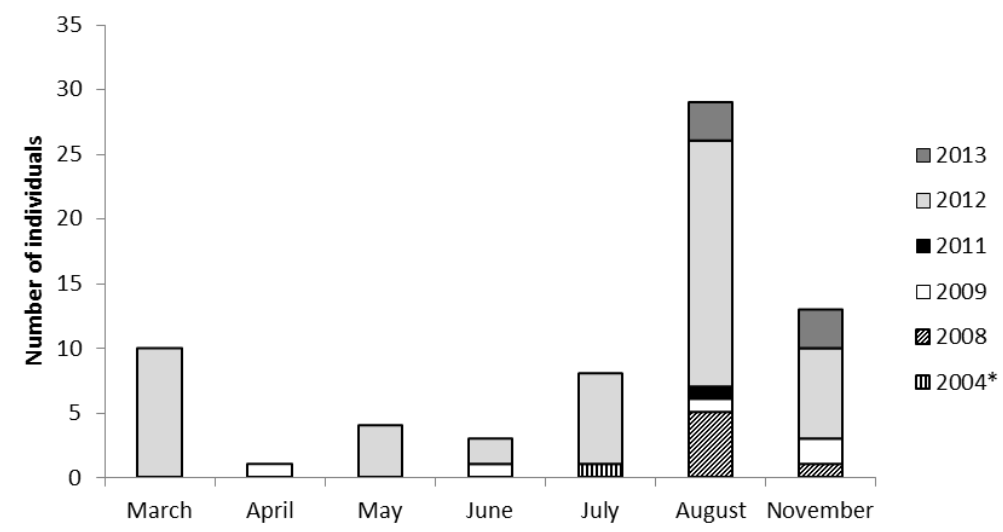

Figure 1: Number of individuals sampled in 2014 in the Gironde estuary per month of capture and per cohort *No stocking occurred in 2004, this fish may come from a reproduction in the wild

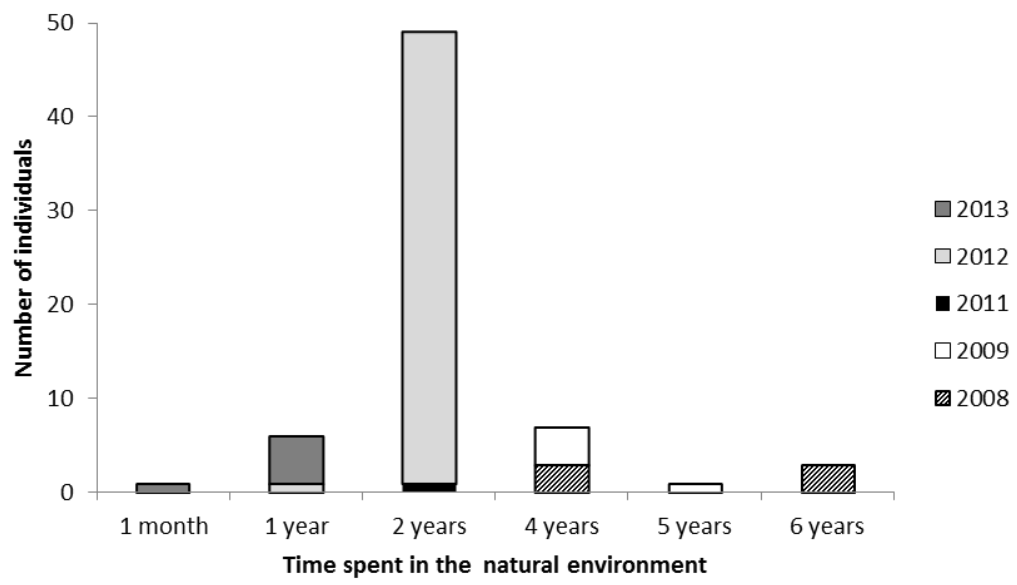

Figure 2: Number of individuals stocked and sampled per cohort and their respective time spent in the natural environment

\section{Blood sampling}

Blood sample from individuals was taken from the caudal vessels. The amount of blood collected corresponded to less than $10 \%$ of the blood volume in the fish on the basis of an average blood volume equal to $2.25 \%$ of the weight of the individual (FAO data) in order to comply with the procedural conditions of the "light type" according to the directive of September 22, 2010, on animal experimentation. Few drops were mixed immediately with $200 \mu \mathrm{L}$ of a cryopreservative buffer and deep frozen in liquid nitrogen until comet assay. Ethanol-fixed blood smears were performed immediately according to the method described in Polard et al. (2011) for micronuclei analysis. Remaining blood volume ( 1 to $2 \mathrm{ml}$ depending on the fish weight) was deposited in heparinized tubes. After centrifugation at 10,000g for $5 \mathrm{~min}$, the plasma was separated for the determination of steroid hormones, organic contaminants and inorganic contaminants; the cell pellet was supplemented with $300 \mu \mathrm{l}$ of RNAlater solution for the analysis of gene expression in blood cells. The plasma and the cell pellet were then frozen at $-20^{\circ} \mathrm{C}$. 
Quantification of inorganic contaminants in plasma

The concentration of 13 metals was measured in the blood plasma from individual fish. The plasma samples were prepared to metal quantification according to the protocol developed by Goulle et al. (2005). In the meantime, two tubes containing the international certified reference material (TORT-2 sample (Lobster hepatopancreas) and DOLT4 samples (Fish liver)) were prepared in order to verify the accuracy of the method. Approximately $100 \mathrm{mg}$ of those CRMs were digested by $3 \mathrm{~mL}$ of nitric acid in polypropylene tubes. Then, this mixture was heated by Hot Block for 3 hours at $100^{\circ} \mathrm{C}$, and after cooling $15 \mathrm{~mL}$ of ultrapure water (Milli-Q®) was added. Finally, 2 blank samples were also prepared in the same conditions ( $3 \mathrm{~mL}$ of $\mathrm{HNO} 3$ before heating and $15 \mathrm{~mL}$ of Milli-Q water added after cooling). However, all metals were analysed by Inductively Coupled Plasma Optical Spectrometry (ICP-OES; Agilent Technologies, 700 Series ICP-OES).

Quantification of organic contaminants in plasma

The target compounds were as follows: polychlorinated biphenyls (PCBs, congeners 28, -52, -101, -118, -138, -153 and -180), organochlorine pesticides (OCPs, $\mathrm{HCB}, \gamma-\mathrm{HCH}$, Heptachlore, cis-chlordane, trans-nonachlor, 2,4' DDE, 4,4' DDE, 4,4' DDD, 2,4' DDT, 4,4' DDT and mirex) and polybromodiphenylethers (PBDEs, congeners -28, -47, -49, $-99,-100,-153,-154,-183$ and -209). Analyses were carried out at individual level, according to the method described in Tartu et al. (2015), which relies on liquid / liquid extraction followed by purification by adsorption chromatography. The extracts were analyzed for polychlorinated biphenyls (PCBs) and organochlorine pesticides (OCPs) by gas chromatography coupled to an electron capture detector (GC-ECD). Polybromodiphenylethers (PBDEs) were determined by GC hyphenated with mass spectrometry (GC-MS) (Luna Costa et al. 2015).

\section{Quantification of steroid hormones in plasma}

The steroid plasma levels were measured from plasma extracts using the competitive enzyme immuno assay (ELISA) method developed for 11 ketotestosterone (11KT) (Cuisset et al. 1994), and adapted for testosterone (T), and 17 $\beta$ estradiol $\left(\mathrm{E}_{2}\right)$. Pure steroids used for standard $\left(11 \mathrm{KT}, \mathrm{T}, \mathrm{E}_{2}\right)$ were purchased from Sigma. Bovine Serum Albumin (BSA) was R.I.A grade (Fraction V, Sigma A-7888). The secondary antibody (Mouse monoclonal anti rabbit IgG) was purchased from SpiBio (Saclay, FRANCE). Solid phase enzyme immunoassay was performed on 96 wells flatbottomed microtiter plates, (Maxisorp) purchased from NUNC. Measurements were achieved at $405 \mathrm{~nm}$ using a MRX microplate reader (DYNATECH). The free steroids were extracted from $0.5 \mathrm{ml}$ aliquots of plasma using $2 \mathrm{ml}$ of a mixture made of ethylacetate/cyclohexane (1:1). Each sample was analysed in duplicate. The 11KT standard curve and the crossing activity of specific anti-11KT antibody, (rabbit anti-11KT serum) were previously described (Cuisset et al. 1994). ELISA for $E_{2}$ or $T$ were adapted from schedule previously described for $11 \mathrm{KT}$. Standard curves obtained using pure steroid dissolved in assay buffer, ranged from $7.8 \mathrm{pg} \cdot \mathrm{ml}^{-1}$ to $16,000 \mathrm{pg} \cdot \mathrm{ml}^{-1}$. The specific anti-T antibody was previously described (Nash et al. 2000). The enzymatic tracers used for $E_{2}$ and $T$ were purchased from SpiBio (Saclay, France). 
DNA damage analysis in blood cells

Comet assay: blood samples diluted in cryopreservative buffer (1/100; $250 \mathrm{mM}$ sucrose, $40 \mathrm{mM}$ trisodium citrate, $5 \%$ dimethyl sulfoxide, $\mathrm{pH} 7.6$, adjusted with $1 \mathrm{M}$ citric acid) were rapidly thawed before the alkaline comet assay processed according to the protocol produced by Singh et al. (1998) with minor modifications. 50 $\mu \mathrm{L}$ of cell suspension was added to $100 \mu \mathrm{L}$ of $1 \%$ low melting point agarose (LMPA) and two gels of $50 \mu \mathrm{L}$ (about 10,000 cells/gel) were layed down on a precoated slide. Slides were placed in a freshly prepared lysing solution at $4{ }^{\circ} \mathrm{C}$ for $1 \mathrm{~h} 30$, then placed in an electrophoresis tank $(0.3 \mathrm{M} \mathrm{NaOH}, 1 \mathrm{mM}$ EDTA; $\mathrm{pH}>13)$ for $30 \mathrm{~min}$ to allow the DNA to unwind. Electrophoresis was carried out at $25 \mathrm{~V}, 300 \mathrm{~mA}$ for $20 \mathrm{~min}$. DNA damage was expressed as percentage tail DNA (Hartman et al. 2003), and 100 randomly selected nucleoids were analyzed on two replicated gels. Image analysis was performed with the Comet 4.0 software (Perspective instruments Ltd.). Heavily damaged cells exhibiting a specific microscopic image (commonly referred to as hedge-hogs or ghost cells) are considered to be apoptotic or necrotic cells as previously described (Olive \& Banath, 1995). These cells were excluded from data collection.

Micronuclei (MN) were counted on individuals from ethanol-fixed blood smears. After staining the cells with acridine orange $(0.003 \%$ in PBS Dulbecco), the observations were made by fluorescence microscopy (Olympus BX4 microscope, U-MWB2 filter) at a 1000 fold magnification. For each sturgeon, 2000 erythrocytes were counted. Micronuclei exhibiting the same yellow-green fluorescence as the nucleus were scored. Results were recorded as permille (\%) of micronucleated cells compared with the total number of counted cells.

\section{Genes' expression in blood cells}

Taking the opportunity that fish red cells are nucleate, we have checked the expression level of genes related to detoxification, immunity and reproduction processes in the blood cells. Total RNA extraction from blood samples was performed with the kit "SV Total RNA Isolation system" (Promega) following the supplier's recommendations. Samples were homogenized using the MP fastprep®-24 (Biorad, $6 \mathrm{~m} / \mathrm{s}, 40 \mathrm{~s}$ ) with $14.4 \mathrm{~mm}$ diameter ceramics beads (MP Biomedicals, Lyssing Matrix D Bulk).

The Reverse transcription was performed using a kit purchased from Promega (GoScript Reverse Transcription System). $1 \mu \mathrm{L}$ of oligodT $(1 \mu \mathrm{M})$ and $1 \mu \mathrm{L}$ of hexanucleotides $(1 \mu \mathrm{M})$ have been added to $10 \mu \mathrm{L}$ of total purified RNA $(1 \mu \mathrm{g})$. The mix was then heated at $70^{\circ} \mathrm{C}$ for 5 minutes with a thermocycler (Eppendorf Mastercycler) followed by 5 minutes at $4^{\circ} \mathrm{C}$ to allow primer annealing. Subsequently, $1 \mu \mathrm{L}$ of dNTP solution $(10 \mathrm{mM}), 4 \mu \mathrm{L}$ of activity buffer, 1.5 $\mu \mathrm{L}$ of $\mathrm{MgCl}_{2}(25 \mathrm{mM}), 1 \mu \mathrm{L}$ of reverse transcriptase $(1 \mathrm{U} / \mu \mathrm{L})$ and $0.5 \mu \mathrm{L}$ or RNAsine were added. The reverse transcription reaction was performed for $1 \mathrm{~h}$ at $42^{\circ} \mathrm{C}$ in a thermocycler. The cDNAs thus obtained were stored at $-20^{\circ} \mathrm{C}$ pending analysis by quantitative real-time PCR reaction.

Quantitative real-time PCR

Nineteen genes were investigated and specific primer-pairs designed with primer3plus software (Table 1). Real-time qPCR was carried out using GoTaq® qPCR Master Mix kit (Promega). PCR reactions contained $17 \mu \mathrm{L}$ of a mixture of Nuclease-Free Water and GoTaq ${ }^{\circledR}$ qPCR Master Mix containing the SyberGreen fluorescent dye, $2 \mu \mathrm{L}$ of specific primer pairs mix $(200 \mu \mathrm{M}$ each) and $1 \mu \mathrm{L}$ of cDNA. Real-time quantitative PCR reactions were performed in a Mx3000P® qPCR System (Stratagene). The amplification program consisted in one cycle at $95{ }^{\circ} \mathrm{C}$ for $10 \mathrm{~min}$, then 45 amplification cycles at $95^{\circ} \mathrm{C}$ for $30 \mathrm{~s}, 60^{\circ} \mathrm{C}$ for $30 \mathrm{~s}$ and $72{ }^{\circ} \mathrm{C}$ for $30 \mathrm{~s}$. Specificity was determined for each reaction 
from the dissociation curve of the PCR products. This dissociation curve was obtained by following the SYBR Green fluorescence level during a gradual heating of the PCR products from 60 to $95^{\circ} \mathrm{C}$.

Cycle thresholds $(\mathrm{Ct})$ were obtained from $\mathrm{MxPro}^{\mathrm{TM}} \mathrm{qPCR}$ software for each gene. Two different reference genes were investigated (Rpl7 and EF1 $\alpha$ ) and were found to be stable in our conditions. Consequently, relative quantification of each gene expression level was normalized according to the mean $\mathrm{Ct}$ value of these two reference genes according to the $2 \Delta \mathrm{Ct}$ methods described by Livak \& Schmittgen (2001).

\section{$\underline{\text { Data analysis }}$}

DNA damage: Global linear models (Glms) were used to identify variables that could influence DNA damage indicators (i.e. Comet tail DNA and MN rate). Data were log-transformed to fulfill normality assumption. Post-hoc Tukey tests were carried out when necessary. Explanatory variables tested were fork length, weight, month of capture, season, age at release, cohort and time spent in captivity. We also tested inorganic and organic contaminant effect. Correlation between comet tail DNA and MN rate were tested with Pearson correlation coefficient.

- Gene expression in blood cells: The $2 \Delta \mathrm{Ct}$ values were obtained for each gene expression, according to the method described by Livak \& Schmittgen (2001), after comparison to housekeeping genes means values. Every fish was thus represented by seventeen $2 \Delta \mathrm{Ct}$ values (one per gene tested) which were used as quantitative variables and integrated in PCA or ANOVA, in order to evaluate the correlation with other variables

Inorganic contaminants

Among the inorganic contaminant analyzed, 6 elements were under the limit of detection: $\mathrm{Ag}, \mathrm{Cd}, \mathrm{Cr}, \mathrm{Ni}, \mathrm{Pb}$ and $\mathrm{V}$. Then we focus the analysis on $\mathrm{As}, \mathrm{Co}, \mathrm{Cu}, \mathrm{Fe}, \mathrm{Mn}, \mathrm{Se}$ and $\mathrm{Zn}$. Glms were then used to assess their values function of fork length, weight, month of capture, season, age at release, cohort and time spent in captivity. Data were logtransformed to fulfil normality assumption and post-hoc Tukey tests were carried out when necessary.

Organic contaminants

Correlation between $\Sigma$ PCBs, $\sum$ PBDEs and $\sum$ OCPs were tested with Pearson correlation coefficient. Glms were used to identify organic contaminants relationship with ecological variables. Data were log-transformed to fulfil normality assumption. Post-hoc Tukey tests were carried out when necessary. Explanatory variables tested were fork length, weight, month of capture, season, age at release, cohort and time spent in captivity.

Multivariate analysis PCA 
Table 1: Specific primer-pairs and functions of the different genes used

\begin{tabular}{|c|c|c|}
\hline Gene & Sequence 5'-3' & Name - Function \\
\hline$r p l 7$ & $\begin{array}{l}\text { GGGCATTGTCAACCAGAGG }^{\mathrm{a}} \\
\text { CTTCTCCGACTTCGCCAG }^{\mathrm{b}}\end{array}$ & Ribosomal protein L7 (housekeeping gene) \\
\hline efl $\alpha$ & $\begin{array}{l}\text { CGTTTCCACGGCGGAT }^{\mathrm{a}} \\
\text { CCCCTGCGTCTGCCTC }^{\mathrm{b}}\end{array}$ & Elongation factor $1 \alpha$ \\
\hline $\operatorname{sod} M n$ & $\begin{array}{l}\text { GACCACGTTCCAGATCGC }{ }^{\mathrm{a}} \\
\text { GGCTGGCTGGGGTTCA }^{\mathrm{b}}\end{array}$ & $\begin{array}{l}\text { Superoxide dismutase - Oxidative stress } \\
\text { response }\end{array}$ \\
\hline $\operatorname{sod} \mathrm{Cu} / \mathrm{Zn}$ & $\begin{array}{l}\text { GTGCGCCGCAAGATGA }^{a} \\
\text { CCAATTACTCCGCAGGCCAA }^{\text {b }}\end{array}$ & $\begin{array}{l}\text { Superoxide dismutase - Oxidative stress } \\
\text { response }\end{array}$ \\
\hline$g p x$ & $\begin{array}{l}\text { CTGCTAAGATCCTGAACACCG } \\
\text { GGTATCCGAACTGGTTACAGG }^{\mathrm{b}}\end{array}$ & $\begin{array}{l}\text { Glutathione peroxydase - Oxidative stress } \\
\text { response }\end{array}$ \\
\hline P53 & $\begin{array}{l}\text { GGTCCAGCAAGAAGAGCCG }^{\mathrm{a}} \\
\text { CCAGGCCCTCTCTCTCC }^{\mathrm{b}}\end{array}$ & $\begin{array}{l}\text { Tumor supressor p53 - Cell cycle } \\
\text { arrest/apoptosis }\end{array}$ \\
\hline bax & $\begin{array}{l}\text { GTAAGCCAAGGCACCCG }^{\mathrm{a}} \\
\text { GGGAAGAGTTGTTGCCCTTT }^{\mathrm{b}}\end{array}$ & $\begin{array}{l}\text { BCL2 associated x protein - Cell cycle } \\
\text { arrest/apoptosis }\end{array}$ \\
\hline$m d r l$ & $\begin{array}{l}\text { AACCCCCAATCCAGCGG }^{\mathrm{a}} \\
\text { CCGCTTTGCTACGGGC }^{\mathrm{b}}\end{array}$ & Multidrug resistance - Detoxification \\
\hline$D N A m t$ & $\begin{array}{l}\text { CAAGCTGGGCTGTAAGAAGG } \\
\text { GCTTGCAGAGGTCAAAGAGG }^{\mathrm{b}}\end{array}$ & Methyl transferase - Epigenetic modification \\
\hline gadd45 & $\begin{array}{l}\text { AGCAACGTCCTGGGAAT }^{\mathrm{a}} \\
\text { GTGCAATATGACTTTTGAGGAACTAAGTG }^{\mathrm{b}}\end{array}$ & Growth arrest DNA damage - DNA repair \\
\hline $\operatorname{rad} 51$ & $\begin{array}{l}\text { AGGAGGAGAATTTTGGACCACA }^{\mathrm{a}} \\
\text { CCAATTTCGCCGCCTCTG }^{\mathrm{b}}\end{array}$ & DNA repair \\
\hline LHR & $\begin{array}{l}\text { TCCTCAACACCTCTCCGACT }^{\mathrm{a}} \\
\text { GCACAGCAGTGACTGGGATA }^{\mathrm{b}}\end{array}$ & Luteinizing hormone receptor - Reproduction \\
\hline$A R$ & $\begin{array}{l}\text { GCCCTCAGGATAGTATGATTACTCAC }{ }^{\text {a }} \\
\text { GGGCTCTGGGTAGGCTT }^{\mathrm{b}}\end{array}$ & Androgen receptor - Reproduction \\
\hline EstR & $\begin{array}{l}\text { AAGCTGTGTTGAGGGTATGG }{ }^{\mathrm{a}} \\
\text { CCAGTAGTAGTTGAATGGTCTGGC }^{\mathrm{b}}\end{array}$ & Estrogen receptor - Reproduction \\
\hline $\operatorname{sox} 9$ & $\begin{array}{l}\text { TCAGCTGCTCGGTCTTGATG }^{\mathrm{a}} \\
\text { GGTCACTTACACTGGCAGCT }^{\mathrm{b}}\end{array}$ & Transcription factor - Reproduction \\
\hline$d m t 1$ & $\begin{array}{l}\text { AACATGCCAGGCTGGTACTC }{ }^{\mathrm{a}} \\
\text { AGGAGACCCATCAGCCAGAT }^{\mathrm{b}}\end{array}$ & Divalent metal transporter \\
\hline perf & $\begin{array}{l}\text { GGGCTGCGTCCAGATTCTTA }^{\mathrm{a}} \\
\text { TTCCAGCTTCTGCCCAGATG }^{\mathrm{b}}\end{array}$ & Perforin - Immunity \\
\hline$M h C 1$ & $\begin{array}{l}\text { GATCCACGAGCTTTCCTCTG }^{a} \\
\text { TCGATAAGGACACCCTGACC }^{\mathrm{b}}\end{array}$ & $\begin{array}{l}\text { Major histocompatibility complex classe } 1 \text { - } \\
\text { Immunity }\end{array}$ \\
\hline$M h C 2$ & $\begin{array}{l}\text { AGCATGACGGACATGGTGTA }^{\mathrm{a}} \\
\text { ATCTGTTGCGAAGCTCAGGT }^{\mathrm{b}}\end{array}$ & $\begin{array}{l}\text { Major histocompatibility complex classe } 2 \text { - } \\
\text { Immunity }\end{array}$ \\
\hline
\end{tabular}

${ }^{\mathrm{a}}:$ Forward primer

b: Reverse primer

We carried out a Principal Component Analysis (PCA) in order to identify the main correlations in our dataset. Nineteen quantitative variables were taken in account: fork length, weight, Comet tail DNA test, MN rate, hormonal dosage (E2, 11KT, T, E2/T, E2/11KT), inorganic contaminants (N=7: As, $\mathrm{Co}, \mathrm{Cu}, \mathrm{Fe}, \mathrm{Mn}, \mathrm{Se}$ and $\mathrm{Zn}$ ) and organic contaminants (N=3: $\sum$ PCBs, $\sum$ PBDEs and $\sum \mathrm{OCPs}$ ). Qualitative data considered were month of capture, season, cohort (i.e. birth year), age at release (below or equal to 3 months old $v s$ one or two years old), time spent in the natural environment, time spent in captivity, river of release. The 68 individuals were considered in the analysis, however, 
considering that all assays were not made on all individuals (not enough blood per individual for all analysis), missing or left-censored values were approximate using InputePCA method from missMDA package.

PCA was also carried out on the fish on which all the assays made ( $\mathrm{N}=27$ biggest individuals). Twenty-eight quantitative variables were taken in account : total length, weight, Comet tail DNA test, MN rate, hormonal ratio (E2/11KT), inorganic contaminants ( $\sum 7$ metals: As, Co, Cu, Fe, Mn, Se and Zn), organic contaminants (N=3: $\sum$ PCBs, ¿PBDEs and $\sum$ OCPs), gene expression value ( $\mathrm{N}=17$ : p53, Bax, DNAmt, Mdrl, Gadd, Rad51, SodCu, SodMn, gpx, MhC1, MhC2, perf, AR, EstR, LHR, Sox9, Dmt1).

\section{Results}

\section{Inorganic contaminants}

Table 2 gathers all Glms results concerning inorganic contaminants levels. As contamination is significantly lower in spring than in summer-autumn and increases with fish length as well as Se, but this latter relationship is weaker (Figure 3A, B). Individuals captured in June have significant lowest levels for Se than individuals captured in May, July or November (Figure 3C). Co values are significantly higher for individuals captured in spring than for ones captured in summer-autumn (Figure 3D). Cu values vary according to month of capture with higher values in July and March compared to August and smaller values in November compared to March, May or July (Figure 3E). Mn values are significantly higher in August than in all the other months of capture, the highest value was measured for one individual belonging to 2011 cohort captured in August (0.046 mg. L $\mathrm{L}^{-1}$ plasma) (Figure 3F). Zn values are significantly smaller in August and November sampling than in fish captured in March, May or July (Figure 3G). Fe levels are significantly higher for individuals released at young stage (below 3 months old) than for the ones released older (at or above 1 year old) (Figure $3 \mathrm{H})$.

\section{$\underline{\text { Organic contaminants }}$}

Among PCBs, the predominant congeners found were CB-153 (42.5 $\pm 11.1 \%$ of $\sum$ PCBs), CB-138 (29.9 $\left.\pm 7.6 \%\right)$ and CB-180 (18.0 $\pm 8.3 \%)$ and, among OCPs, 4,4'-DDE $(52.6 \pm 40.5 \%)$ and 4,4'-DDD $(37.1 \pm 32.1 \%)$ were prevalent while among PBDEs, BDE-47 was the only detected congener. Concentrations of PCBs, OCPs and PBDEs were generally low: the sum of 7 PCBs varied from 1 to $10 \mathrm{ng} \cdot \mathrm{g}^{-1}$, for 8 OCPs from $100 \mathrm{pg}$ to $1 \mathrm{ng} \cdot \mathrm{g}^{-1}$, and for 8 PBDEs from 10 to $100 \mathrm{pg} . \mathrm{g}^{-1}$. A positive correlation was found between $\sum$ PCBs and $\sum$ PBDEs (correlation coefficient=0.69, p-value $=2.968 \mathrm{e}-8$ ) as well as between $\sum$ PCBs and $\sum$ OCPs (correlation coefficient $=0.45$, p-value $\left.=0.0009\right)$ and $\sum$ PBDEs and $\sum$ OCPs (correlation coefficient $=0.50$, p-value $=0.0002$ ).

Table 3 gathers all Glms results concerning organic contaminants levels. Glms results reveal that, as fork length increases, PCBs contamination decreases significantly (Figure 4A). PCBs levels are significantly higher for 2009 cohort than for 2008 cohort but levels of 2009 cohort are significantly lower than for 2012 and 2013 cohorts (Figure 4B). PBDEs levels are related to month of capture, levels in March being significantly higher than in May, July, August and November (Figure 4C). OCPs were related to season, contamination being higher in spring than in SummerAutumn (Figure 4D). 
Table 2: Significant explanatory variables for the 7 inorganic contaminants measured in A. sturio.

\begin{tabular}{|l|l|l|}
\hline Inorganic contaminants & Significant explanatory variables & p-value \\
\hline $\mathrm{As}$ & Fork length & $8.478 \mathrm{e}^{-6}$ \\
\hline & Season & 0.005010 \\
\hline $\mathrm{Co}$ & Season & 0.000172 \\
\hline $\mathrm{Cu}$ & Month & $8.815^{-8}$ \\
\hline $\mathrm{Fe}$ & Age at release & 0.03013 \\
\hline $\mathrm{Mn}$ & Month & $2.2 \mathrm{e}^{-16}$ \\
\hline $\mathrm{Se}$ & Fork length & 0.00674 \\
\hline & Month & 0.004127 \\
\hline $\mathrm{Zn}$ & Month & $3.311 \mathrm{e}^{-9}$ \\
\hline
\end{tabular}

Table 3: Significant explanatory variables for the organic contaminants measured in A. sturio.

\begin{tabular}{|l|l|l|}
\hline Organic contaminants & Significant explanatory variables & p-value \\
\hline PCBs & Fork length & $7.607 \mathrm{e}^{-6}$ \\
\hline & Cohort & 0.003449 \\
\hline PBDEs & Month & $1.581 \mathrm{e}^{-7}$ \\
\hline OCPs & Season & 0.002449 \\
\hline
\end{tabular}

\section{PCA results on the whole data set}

The first two components of the multivariate analysis explained $43 \%$ of the variance (Figure 5), the main ecological explanatory variables being the cohort (Figure 5B), the season (Figure 5C) and the time spent in the natural environment (Figure 5D).

The first axis highlighted that Co, PCBs, OCPs and PBDEs were strongly correlated together. This combination of contaminants varied regarding the seasons. The individuals captured in spring (mainly March) were more contaminated in Co, PCBs and PBDEs than individuals captured at the end of the summer (mainly August) (data not shown)

The second axis showed that individual weight, fork length, two hormonal dosages (11KT and T) and Cu levels were strongly correlated together (Figure 5A). All these descriptors depended on the time spent in the natural environment and the cohort. The biggest individuals which were also the oldest, had higher levels of $\mathrm{Cu}, 11 \mathrm{KT}$ and $\mathrm{T}$ than the smaller and younger individuals that had spent less time in the natural environment.

For $\mathrm{Cu}$ contamination, the tendency seems driven by the oldest (2004 cohort) and the youngest individuals (2013 cohort, less time spent in the natural environment), for the other cohorts (2008-2012) the average level of $\mathrm{Cu}$ is about $0.27 \mathrm{mg} . \mathrm{L}^{-1}$ plasma (Data not shown ). 

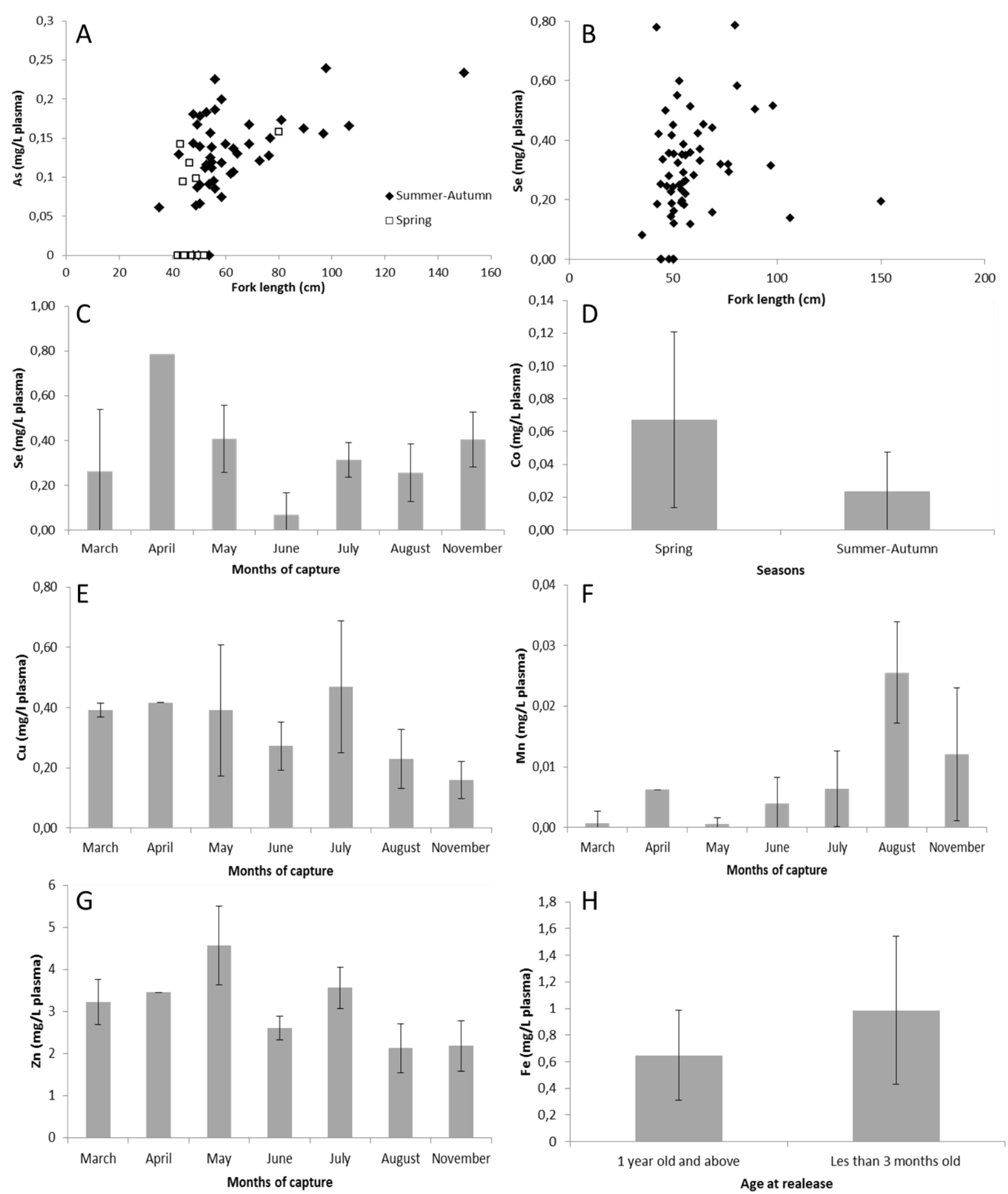

Figure 3: Concentrations of metals in the plasma of A. sturio according to their explanatory variables. (mean+/- SD) 

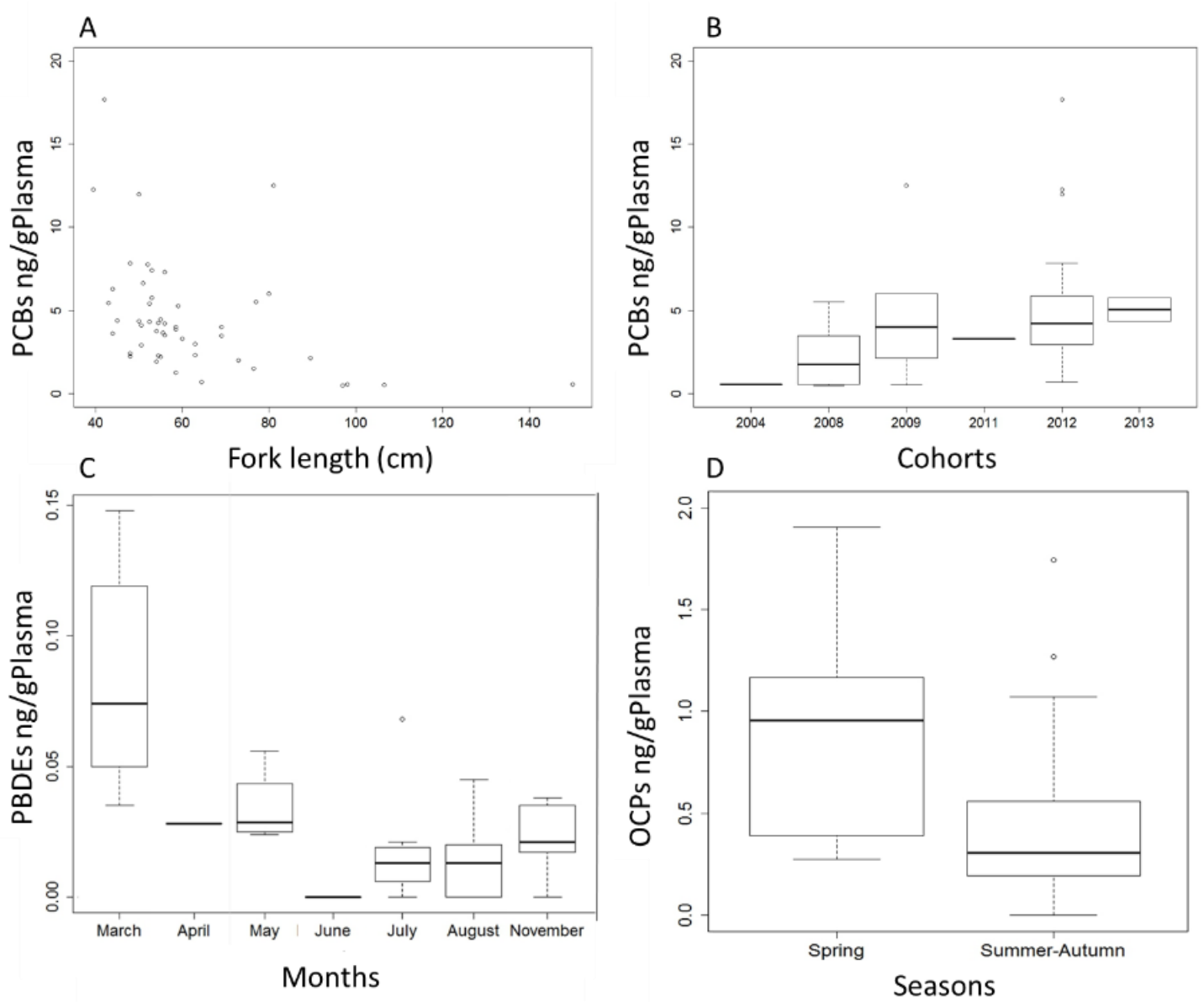

Figure 4: Concentrations of persistent organic pollutants in the plasma of $A$. sturio according to their explanatory variables. PCBs are plot against fork length (A) and box plots of PCBs (B), PBDEs (C) and OCPs (D) according to their explanatory qualitative variables are represented.

\section{$\underline{\text { Sex steroid hormones }}$}

The Figure 6 represents the sex steroid hormone levels measured in the plasma at the individual level. Among the three steroid hormones measured, in most fish the predominant one was estradiol (E2) that was not correlated to the size or the age of the fish (see multivariate PCA results). Eight individuals had E2 levels $>300 \mathrm{pg} \cdot \mathrm{mL}^{1}$ were found in fish from three cohorts (2012, 2009 and 2008); the highest level was found in one 2-years old individual (995 pg.mL $\left.{ }^{-1}\right)$. Levels of 11 ketotestosterone $(11 \mathrm{KT})$ and testosterone $(\mathrm{T})$ were low, most values being below $100 \mathrm{pg} \cdot \mathrm{mL}^{-1}$. Eleven fish only among 61 had levels over $100 \mathrm{pg} \cdot \mathrm{mL}^{-1}$. Testosterone levels were found to be correlated to $11 \mathrm{KT}$ levels (r=0.5762; $\mathrm{p}$ value $<0.0005)$, and to E2 levels ( $\mathrm{r}=0.5013$; $\mathrm{p}$ value <0.0005). 11KT levels were correlated to fish weight ( $\mathrm{r}=0.6340$; $\mathrm{p}$ value $=0.004)$, to fork length $(\mathrm{FL})(\mathrm{r}=0.5354$; $\mathrm{p}$ value=0.041) and to age of the fish $(\mathrm{r}=0.6714 ; \mathrm{p}$ value $<0.0005)$. That may partly be due to the oldest (> 10 year) and biggest fish (number 44) exhibiting the highest 11KT levels.

In 2 years-old fish (cohort 2012), individual levels for E2 and T seemed to be higher in spring than during summerautumn period (Figure 7A). Sexing fish was not possible since biopsy of gonad was forbidden on such precious 
specimen. In order to minimize the differences in hormone levels that might be related to the sex, the sum of the three steroids was calculated for each individual: the mean total was found to be significantly higher $(\mathrm{p}<0.05)$ in $\mathrm{spring}$ than during summer-autumn period (Figure 7B). This indicates that hormone levels exhibit seasonal variations in this cohort.
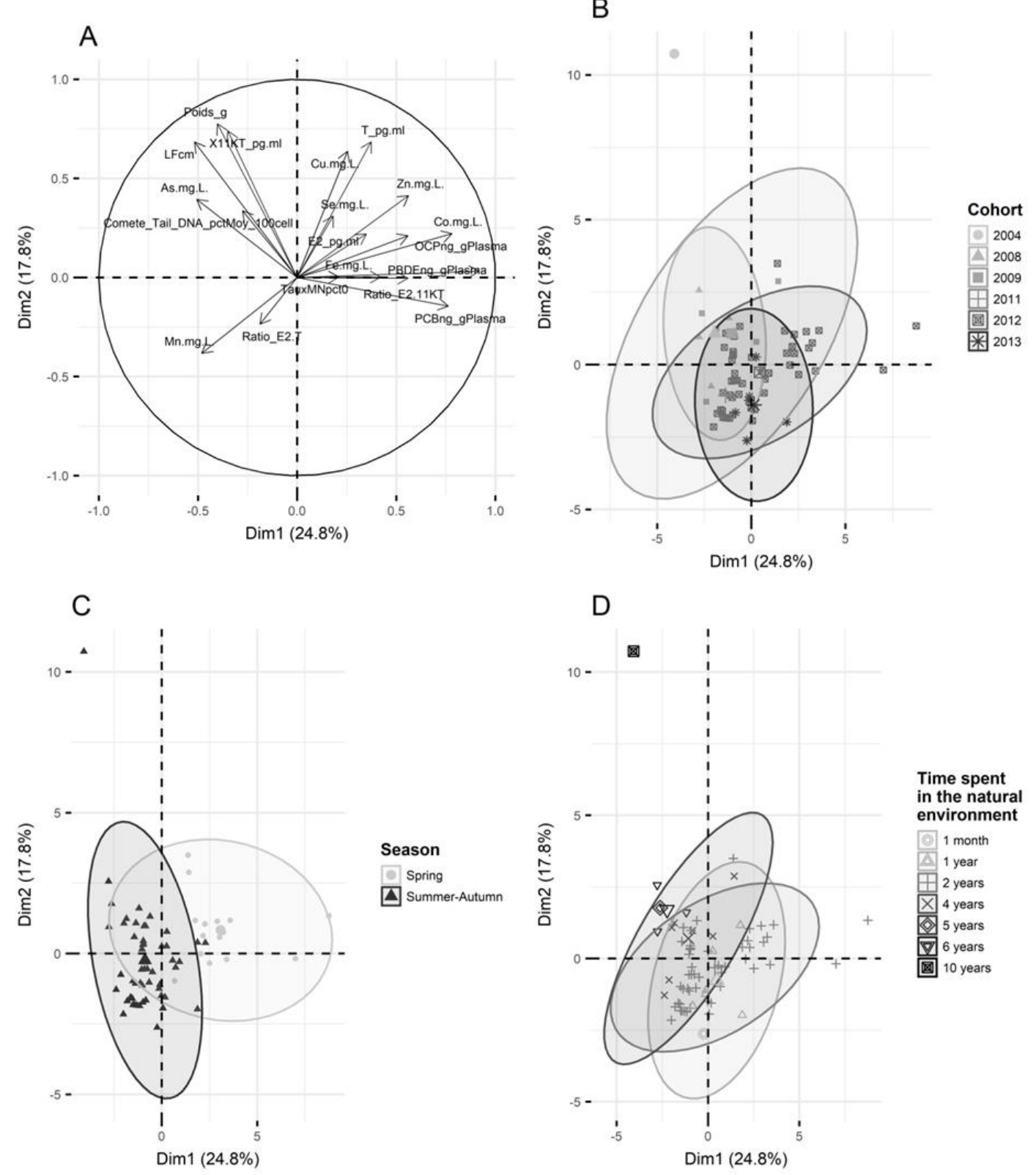

Figure 5: PCA main results for the whole data set: (A) all individuals and all variables; (B, C, D) Distribution of individuals according to the cohort (B) to the season (C), to the time spent in the natural environment (D). 


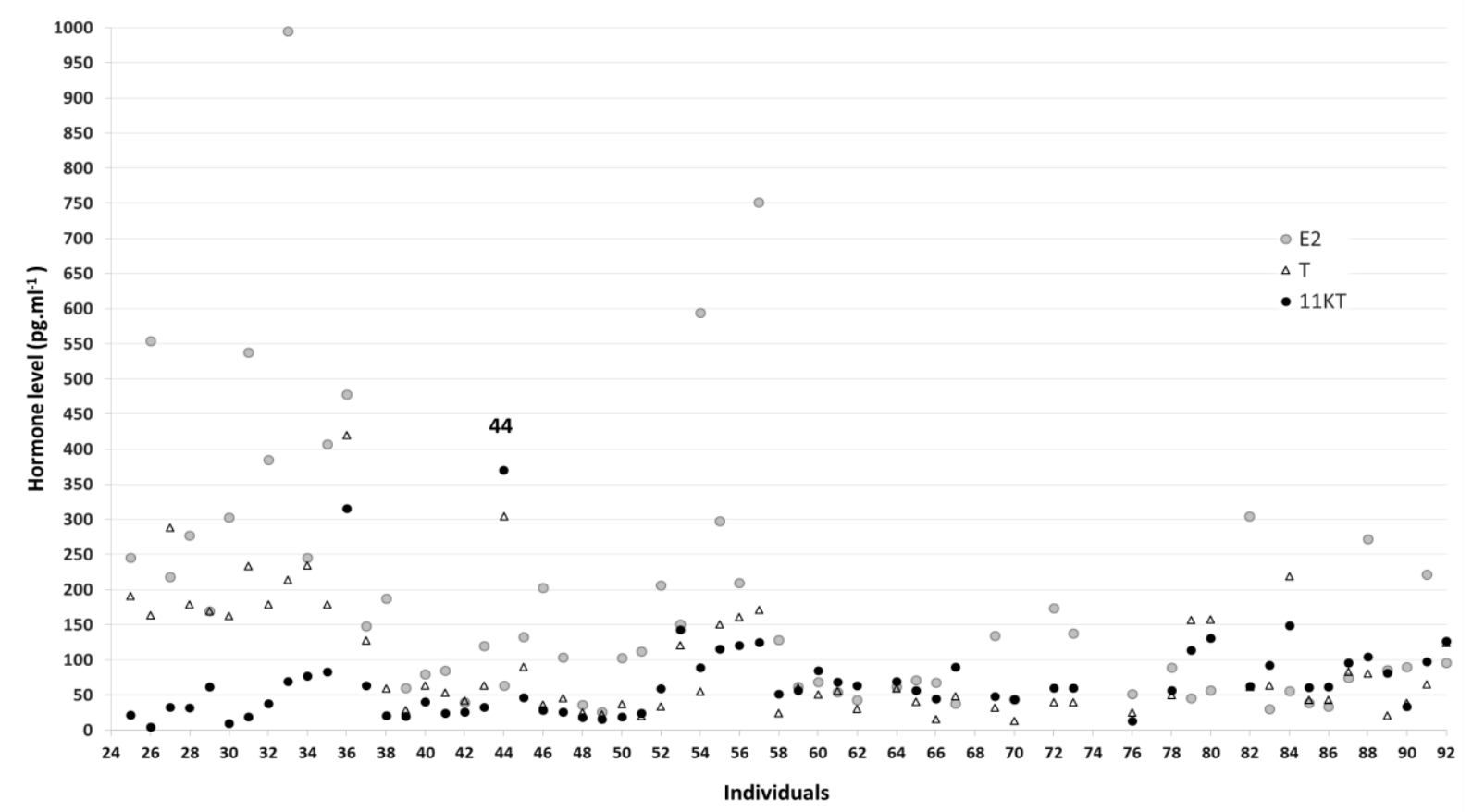

Figure 6: Estradiol ( $\left.\mathrm{E}_{2}\right)$, Testosterone $(\mathrm{T})$ and 11 ketotestosterone (11KT) plasma levels (pg.ml $\left.{ }^{-1}\right)$ in 61 individuals of A. sturio. Number 44 corresponds to the biggest individual > 10 year.
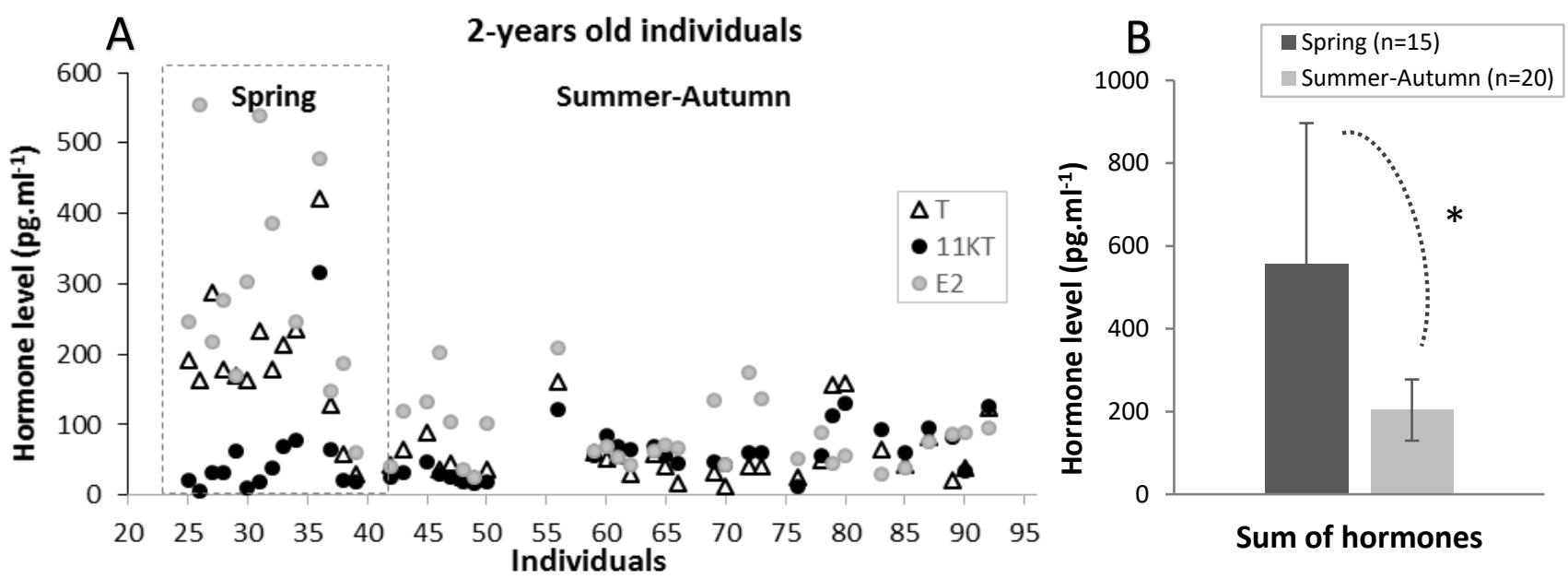

Figure 7: Variation of hormone plasma levels of two years-old fish from the cohort 2012. (A) Individuals (B) Sum of the three hormones according to the season (mean $\pm \mathrm{SD}) .{ }^{*}$ indicates a significant difference at 0.05 level.

Genome integrity

Glms results highlighted that comet tail DNA was related to month of capture ( $\mathrm{p}$-value=0.001) and cohort (pvalue $=0.0003)$. $\mathrm{MN}$ rate was related to season $(\mathrm{p}$-value $=0.009)$. Those indicators were not related to inorganic or organic contaminant levels. 
The results of the micronucleus test (MN) show relatively low levels for the majority of individuals, however with a very large inter-individual variability. $\mathrm{MN}$ rate was significantly higher for individuals captured in spring than in summer-autumn (Figure 8A) and higher for the smaller fish (fork length below $60 \mathrm{~cm}$ ). On the contrary, MN rate was the lowest for the oldest individual. Regardless of the season, MN rate was quite high for three individuals (values $>16 \%$ ). Comet tail DNA rate was higher in November sampling compared to all other months of capture and it was lower for cohort 2013 compared to 2008 and 2012 cohorts (Figure 8 B). The highest values were for some individuals belonging to the 2012 cohort (Figure 8B). No correlation could be found between the comet values and the $\mathrm{MN}$ rate ( $\mathrm{p}$-value $=0.9815)$.
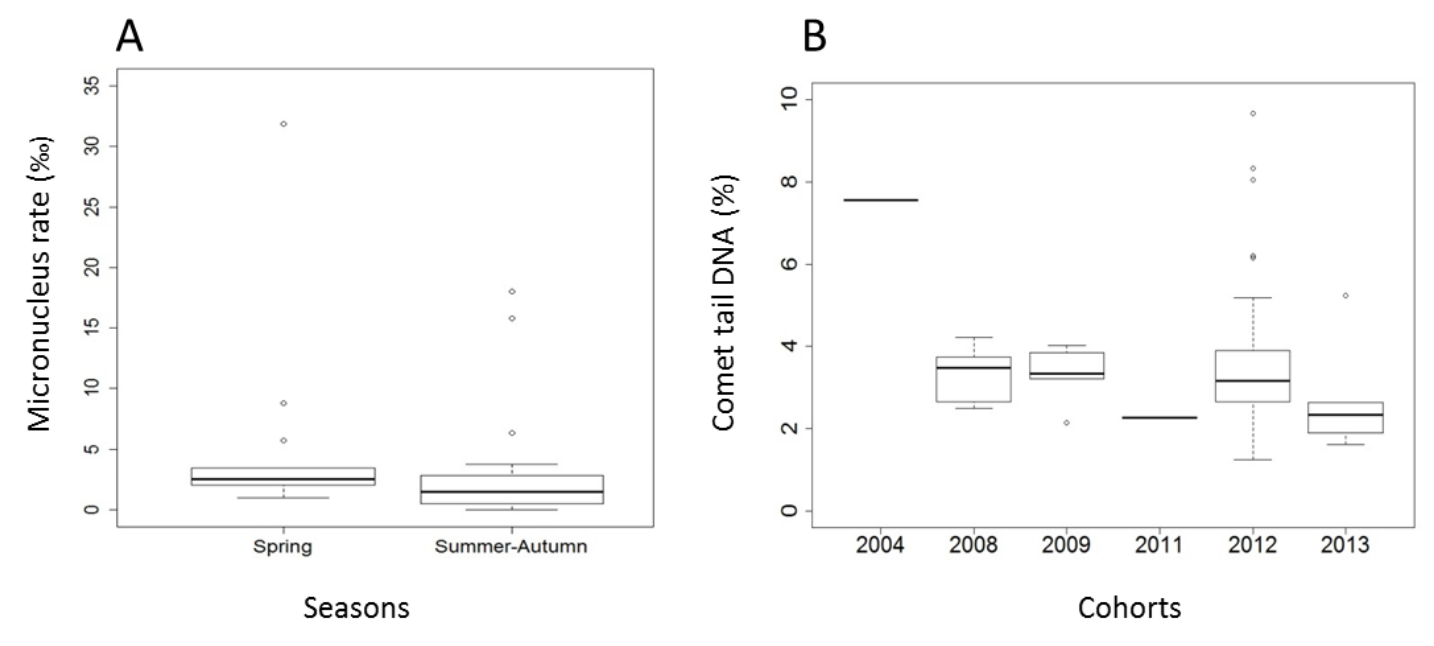

Figure 8: Micronucleus rate according to A. sturio length (A) and box plot of the comet tail DNA values for each cohorts (B).

\section{Gene expressions in blood cells}

$2 \Delta \mathrm{Ct}$ values proved the relative expression of the seventeen genes of interest compared to the mean values of the housekeeping genes (rpl7 and ef1 $\alpha$ ) in blood cells. $2 \Delta \mathrm{Ct}$ values were used for the comparison between fish and from gene to another. For the first time, the transcription of genes encoding proteins involved in the reproduction such as androgen receptor $(A R)$, estrogen receptor $(E s t R)$, LH receptor $(L H R)$, sox9, was found in blood cells. PCA performed on the individuals on which all the assays could be carried out ( $\mathrm{N}=25$ individuals) demonstrated 5 main groups of variables: on one hand that with $E s t R, A R, L H R$, perf, sodCu, mdrlgene expressions and $\sum \mathrm{PCBs}$; on a second hand a group including dmt1, DNAmt, rad51, Gadd45 and p53 gene expressions with Sox9 and MhC2 gene expressions not far ; a third group where $\sum$ PBDEs, $\sum$ Metals, MN and E2/11KT ; a fourth group with sodMn, bax, Gpx gene expression and $\sum$ OCPs. Age, total length, weight form another group with $M h C 1$ gene expression. Comet tail DNA value was not correlated to any other parameters, including $\mathrm{MN}$ rate (Figure 9A). Interestingly, a strong correlation was found between the expression of genes encoding proteins involved in reproduction (EstR, AR, and sox9) and the plasma concentration of organic contaminants such as $\sum$ PCBs and $\sum$ OCPs (Table 4). 
The distribution of individuals in relation to both dimensions is presented in Figure 9B; the correlation values using the 25 fish are shown in Table 4.

Table 4: the significant correlation values obtained between the variables for the 25 selected individuals.

\begin{tabular}{|c|c|c|c|c|c|c|c|c|c|c|c|c|c|}
\hline Variable & sodCu & perf & $M h C_{2}$ & $\operatorname{sox} 9$ & $A R$ & EstR & $L H R$ & Dmt 1 & E2/11KT & rad51 & Gadd45 & $p 53$ & Bax \\
\hline PCBs & $\begin{array}{r}.6215 \\
\mathrm{p}=.002\end{array}$ & $\begin{array}{r}.6785 \\
p=.001\end{array}$ & $\begin{array}{r}.6784 \\
\mathrm{p}=.001\end{array}$ & $\begin{array}{r}.6784 \\
\mathrm{p}=.001\end{array}$ & $\begin{array}{r}.6786 \\
\mathrm{p}=.001\end{array}$ & $\begin{array}{r}.6870 \\
p=.000\end{array}$ & & & $\begin{array}{r}.4747 \\
\mathrm{p}=.026\end{array}$ & & & & $\begin{array}{r}.6061 \\
p=.003\end{array}$ \\
\hline OCPs & $\begin{array}{r}.7128 \\
p=.000\end{array}$ & $\begin{array}{r}.6360 \\
p=.001 \\
\end{array}$ & $\begin{array}{r}.6357 \\
p=.001 \\
\end{array}$ & $\begin{array}{r}.6357 \\
p=.001 \\
\end{array}$ & $\begin{array}{r}.6361 \\
p=.001 \\
\end{array}$ & $\begin{array}{r}.6480 \\
p=.001 \\
\end{array}$ & & & & & & & $\begin{array}{r}.6345 \\
p=.002 \\
\end{array}$ \\
\hline $\operatorname{sodCu}$ & & $\begin{array}{r}.7799 \\
p=.000 \\
\end{array}$ & $\begin{array}{r}.7794 \\
p=.000\end{array}$ & $\begin{array}{r}.7794 \\
p=.000\end{array}$ & $\begin{array}{r}.7802 \\
p=.000 \\
\end{array}$ & $\begin{array}{r}.8190 \\
\mathrm{p}=.000\end{array}$ & $\begin{array}{r}.4987 \\
\mathrm{p}=.018 \\
\end{array}$ & & & & & & $\begin{array}{r}.8242 \\
\mathrm{p}=.000 \\
\end{array}$ \\
\hline sodMn & & & & & & & & $\begin{array}{r}.4756 \\
\mathrm{p}=.025 \\
\end{array}$ & & $\begin{array}{r}.6767 \\
p=.001\end{array}$ & $\begin{array}{r}.6726 \\
p=.001\end{array}$ & $\begin{array}{r}.6735 \\
\mathrm{p}=.001\end{array}$ & AR \\
\hline Gpx & & & & & & & $\begin{array}{r}.5846 \\
\mathrm{p}=.004 \\
\end{array}$ & & & & & $\begin{array}{r}.5251 \\
\mathrm{p}=.012\end{array}$ & \\
\hline EstR & & $\begin{array}{r}.9967 \\
\mathrm{p}=0.00\end{array}$ & $\begin{array}{r}.9967 \\
\mathrm{p}=0.00\end{array}$ & $\begin{array}{r}.9966 \\
\mathrm{p}=0.00\end{array}$ & $\begin{array}{r}.9967 \\
\mathrm{p}=0.00\end{array}$ & & & & & & & & $\begin{array}{r}.9098 \\
\mathrm{p}=.000\end{array}$ \\
\hline Perf & & & $\begin{array}{l}1.0000 \\
\mathrm{p}=0.00\end{array}$ & $\begin{array}{l}1.0000 \\
p=0.00\end{array}$ & $\begin{array}{l}1.0000 \\
\mathrm{p}=0.00\end{array}$ & & & & & & & & $\begin{array}{r}.9011 \\
\mathrm{p}=.000\end{array}$ \\
\hline$M h C_{2}$ & & & & $\begin{array}{l}1.0000 \\
p=0.00\end{array}$ & $\begin{array}{l}1.0000 \\
p=0.00\end{array}$ & & & & & & & & $\begin{array}{r}.9009 \\
p=.000\end{array}$ \\
\hline$M h C_{1}$ & & & & & & & & & & $\begin{array}{r}.7752 \\
p=.000 \\
\end{array}$ & $\begin{array}{r}.9177 \\
\mathrm{p}=.000\end{array}$ & $\begin{array}{r}.8459 \\
\mathrm{p}=.000\end{array}$ & \\
\hline Dmt 1 & & & & & & & & & & $\begin{array}{r}.4698 \\
\mathrm{p}=.027\end{array}$ & $\begin{array}{r}.5223 \\
\mathrm{p}=.013 \\
\end{array}$ & $\begin{array}{r}.4880 \\
\mathrm{p}=.021 \\
\end{array}$ & \\
\hline $\operatorname{sox} 9$ & & & & & $\begin{array}{l}1.0000 \\
p=0.00\end{array}$ & & & & & & & & $\begin{array}{r}.9009 \\
\mathrm{p}=.000\end{array}$ \\
\hline & & & & & & & $\begin{array}{c}\boldsymbol{m d r} \boldsymbol{I} \\
.9543 \\
\mathrm{p}=.000\end{array}$ & & & & & & $\begin{array}{r}A R \\
.9013 \\
\mathrm{p}=.000\end{array}$ \\
\hline
\end{tabular}
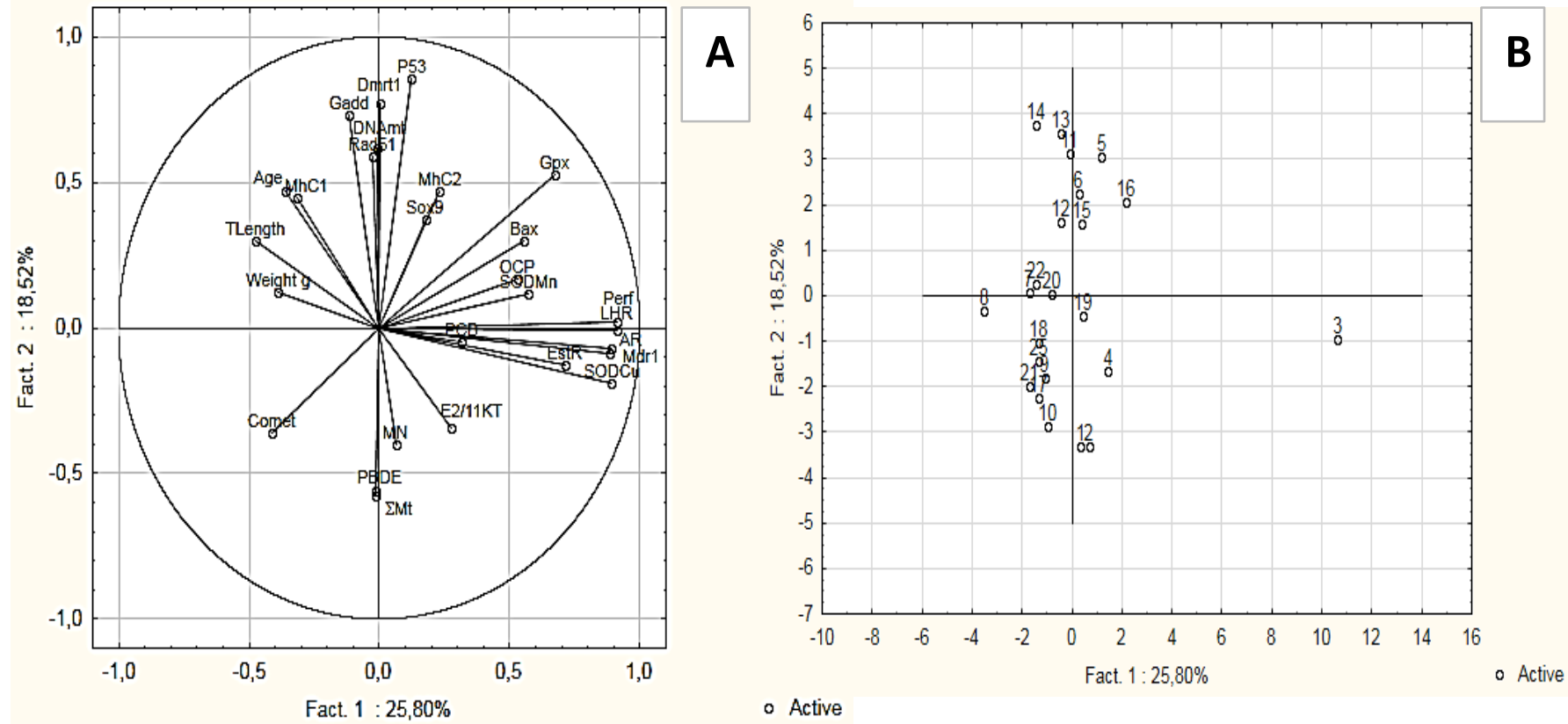

Figure 9: PCA results for 25 selected fish for which all measures were available. 27 variables were used, including gene expression ( $\mathrm{N}=17)$, organic contaminants ( $\mathrm{N}=3$ : PCBs, OCPs, PBDEs), inorganic contaminants $(\mathrm{N}=1$ : $\Sigma 7$ Metals), DNA Damage ( $\mathrm{N}=2$ : Comet, $\mathrm{MN})$ hormones $(\mathrm{N}=1$ : $\mathrm{E} 2 / 11 \mathrm{KT}$ ratio), fish total length, age and weight. 


\section{Discussion}

The present results describing biomarkers and chemical analyses from European sturgeon are the very first data obtained on specimen from the natural environment. All the measures were performed on blood at the individual level. Every data previously described in this sturgeon species, European sturgeon, were from reared sturgeons only.

\section{Contaminants measured in the blood of A. sturio from the Gironde estuary}

Globally, inorganic contaminants values are low among the sampled individuals. Many essential elements $(\mathrm{Co}, \mathrm{Cu}$, $\mathrm{Mn}, \mathrm{Se}, \mathrm{Zn}$ ) tend to vary according to month of capture and this may be due to fish diet, or to remobilization of those elements from the sediment depending on water flow and tide intensity. The concentration of two elements, As and $\mathrm{Se}$, increases with fish length which might be correlated to the time spent in the environment. The highest values of $\mathrm{Fe}$ among fish released at or before 3 month-old might be linked to environmental exposure during their early life spent in the rivers compared to fish released at or above one year-old which reach, rapidly after their release, the saline estuary to grow (Acolas et al. 2012, 2017). However, we do not have any data about the Fe content in the water or sediments from the rivers concerned. Research in this field could be considered in next future.

We still do not have any valuable data to compare to our levels measured from the blood of sturgeons. Data previously obtained in the Gironde estuary were reported by Durrieu et al. (2005). They have compared the accumulation of four metals $(\mathrm{Cd}, \mathrm{Hg}, \mathrm{Cu}, \mathrm{Zn})$ in gills, muscles, liver and kidneys in eight fish species from the Gironde estuary. The concentrations were very variable from one organ to another and according to the species. The Cd levels found in kidneys of mugil, Liza ramada and eel, Anguilla anguilla, were respectively 72 and $34 \mu \mathrm{g} \cdot \mathrm{g}^{-1}$ dry weight, but in others species, the level was under $8 \mu \mathrm{g} \cdot \mathrm{g}^{-1}$ dry weight. The accumulation rate varied greatly depending on the organ considered. Different tissue and unit ( $\mu \mathrm{g} \cdot \mathrm{g}^{-1}$ dry weight of tissue), make it difficult to compare to our results ( $\mu \mathrm{g} \cdot \mathrm{ml}^{-1}$ plasma). As a noticeable difference, our samples did not contain significant level of $\mathrm{Cd}$ while high concentrations are currently measured in the Gironde estuary (Lanceleur et al. 2011).

Only a few studies have determined concentrations of PCBs, OCPs or PBDEs in sturgeons and previous works mainly concerned tissues such as liver, muscle or eggs (MacDonald et al. 1997, Kajiwara et al. 2003, Feist et al. 2005; Hosseini et al. 2008; Zhang et al. 2010; Buckler, 2011). Furthermore, very few studies have addressed concentrations of halogenated contaminants in sturgeon plasma ( $\mathrm{Li}$ et al. 2003; Valters et al. 2005), although this non-lethal approach is particularly valuable in the case of endangered species. Li et al. (2003) measured PCBs in the plasma of a Lake sturgeon (Acipenser fulvescens) and they reported $\Sigma \mathrm{PCBs}$ around $10 \mathrm{ng} \cdot \mathrm{g}^{-1}$ wet weight in plasma (Li et al. 2003). The $\Sigma \mathrm{DDT}$ concentration (i.e. sum of 4,4'-DDT, 4,4'-DDD and 4,4'-DDE) was approximately $2 \mathrm{ng} \cdot \mathrm{g}^{-1}$ wet weight in plasma. Although Li et al. (2003) targeted a different species and different locations, such values are within the same order of magnitude than those reported in the present study for sturgeon from the Gironde estuary. Valters et al. (2005) determined plasma concentrations of PBDEs in Lake sturgeon from Lake St. Clair in Canada which are comparable with those measured in this study $\left(<0.1 \mathrm{ng} \mathrm{g}^{-1}\right.$ wet weight). 
PCA on the whole data set

PCA analysis highlighted some gross tendency in our sample. Concerning the highest concentration of Co, PCBs and PBDEs in fish plasma in spring compared to summer-autumn period ( 2 to 3.5 fold time higher), it could be due to a seasonal modification of contaminants present in the estuary and/or to a seasonal modification of the diet of the sturgeons. In 2014, their diet was mainly constituted of Crustacea in spring and of Polychaeta in summer-autumn which contamination by organo halogenated pollutants has recently been documented for the Gironde estuary (Lauzent, 2017).

On the contrary to the first variables, $\mathrm{Cu}$ and fork length, are not correlated to season but to the time spent in the natural environment. $\mathrm{Cu}$ is highest in the oldest fish of 10 year-old, fish that spent a high proportion of its life at sea on the contrary to the other cohorts that have either spent only little time at sea $(2008,2009$ cohorts) or probably lived only in the estuary $(2011,2012,2013$ cohorts). In conclusion, our results do not reveal high inorganic contamination of those fish that represent estuarine sub-fraction of the population of European sturgeon; on the contrary, their contamination level seems reduced as compared to what can be measured from blood plasma, in salmonids (0.69-2.8 ppm) in freshwater or plaice at sea (0.73 ppm) (Sturrock et al. 2013).

\section{Sexual maturity assessed by hormonal levels in $A$. sturio from the Gironde estuary}

This is the very first report on hormonal status of European sturgeon A.sturio captured from the natural environment. Indeed, the previous available studies on hormone levels were reporting on hatchery-reared fish (Davail-Cuisset et al. 2005). All the fish captured in the estuary, except one, were less than 7-years old. According to what is known about the life history of this species, they all were expected to be juveniles. The hormone levels in the present study are consistent with previous measurements in the same hatchery-reared species, and were predictable for juveniles, indicating a still distant maturity (Davail-Cuisset et al. 2011). Since no invasive sampling was allowed, such as biopsy of gonad, we had no idea of fish sex or of the gametogenesis stage, and could not check any correlation with hormone. However, would a biopsy had been done, it would have been useless for cohorts 2011 to 2013 , because of the very small size of gonad on such juveniles. Considering the cohorts 2008 and 2009, a biopsy would certainly have brought significant details including the stage at gametogenesis and the sex of the individuals. Method for sexing sturgeons based on 11KT levels was previously reported in Siberian sturgeons Acipenser baeri (Cuisset 1993; Cuisset et al. 1994, 1995) and was successfully used for several years in fish farms of Southwest France for sexing 3-years old sturgeons. In the stellate sturgeon Acipenser stellatus, captured from the Danube River, good correlations between the E2/11KT ratios and sex were found in young adults (Ceapa et al. 2002). In all these species, the reported E2, T, and $11 \mathrm{KT}$ hormone levels were much higher than that measured presently. However, we can compare the present hormone data to those obtained over a 5-year follow-up on hatchery-reared A. sturio initially aged of 5 years (Davail-Cuisset et al. 2008, 2011). Previous study showed hormonal levels in a slightly higher range than those found presently, at the same age, in accordance with the expected fact that fish grow faster and mature earlier in hatchery than in the wild, due to the constant and regular supply of food in hatcheries. In some 11 year-old reared males approaching the breeding season in May, we measured values for both $\mathrm{T}$ and $11 \mathrm{KT}$ ten to hundred times as high as the present ones (up to 40 ng. $\mathrm{mL}^{-1}$ ) (Davail-Cuisset et al. 2005, 2008). Considering the oldest individual (more than 10 year-old) sampled in the estuary in July 2014, one would assume that it is most likely a male, and expect it to be mature, according to its $\mathrm{T}$ and 
$11 \mathrm{KT}$ levels, size and age. However, July corresponding to the end of the breeding season when gonads regress (Davail-Cuisset et al. 2011) this might explain that this male was not found to be spermiant.

In fish species that follow a seasonal reproduction, it is currently seen that sex hormones levels follow seasonal variations. As demonstrated for the juvenile two year-old cohort, hormonal variations were found annually in sturgeons, with higher levels found in spring than during summer-autumn period. Because the breeding season and spawning of European sturgeon occur from May to the end of June, it is not so surprising to find highest hormone levels during spring, at the onset of gametogenesis in juveniles, and during preparation process of breeding season in adults.

According to the hormone levels found, we did not perform any vitellogenin assay although ELISA technic was available at laboratory, since it would have used and wasted an extra volume of blood plasma, and we assume that fish were too small to have entered vitellogenesis.

In conclusion, the normal patterns observed from all three hormones measured over a one year-study ensure that those fish seems not to be exposed to strong endocrine disruptors that could have disturbed the sex steroid hormone synthesis. The quite low hormonal plasma levels measured in these fish during this one year-study indicate a still distant maturity, which was predictable for 2 to 6 year-old juveniles.

\section{Health status of $A$. sturio from the Gironde estuary}

At the capture, just before the sampling process on the boat, we made a careful examination of the fish. Their general appearance was very satisfactory, and the presence of an external parasite was noticed only three times.

Genome integrity

$\mathrm{MN}$ rate and comet assay values were not found to be correlated (Figures 6A, 9A). It is not so surprising since the two methods measure different endpoints of damage: The $\mathrm{MN}$ is based on quantification of whole chromosomes or fragmented chromosomes that are not incorporated into the main nucleus during mitosis, and qualify definitive damage. The Comet Assay is also an indicator of genotoxicity, detecting DNA strand breaks, that are repairable DNA damage (Araldi et al. 2015; Frenzilli et al. 2009). Both tests generate complementary information, usually used in combination for screening genotoxic effects of environmental pollutants.

For the two tested indicators, values are globally low compared to what can be observed in species under stressors (Akcha et al, 2003, 2004; Hussain et al 2018). The DNA damage level measured in red blood cells of European sturgeon in the present study (mean tail intensity around $2 \%$ ) is in the very low range of the values commonly obtained in erythrocytes of fish from pristine areas (Mitchelmore and Chipman 1998; Frenzilli et al 2009). This indicates a globally good genomic integrity. MN rate are very close to those found in the Russian sturgeon A. gueldenstaedti, whose rate was near 3\% in controls, rising to $12-15 \%$ in fish exposed to metal contamination by sediment (Bickham et al. 1998). Among our samples, 3 individuals, measuring less than $60 \mathrm{~cm}$, had very high $\mathrm{MN}$ rate (up to $30 \%$ ). Possible exposure of these juveniles, during the weeks preceding the capture, to genotoxic agents, hypoxia or other stress such as temperature increases, might have induced $\mathrm{MN}$ formation during hematopoiesis.

In the present study (Figure 5A), DNA damage detected by Comet assay, but not MN rate, was linked to size and weight of the individuals. In mouse, it is known that DNA repair capacities decrease with age, and that DNA damage 
accumulate in older individuals (Bhilwade et al. 2014). Conversely, MN rate is linked to erythropoiesis which decreases with age (Heuser et al. 2008).

$\mathrm{MN}$ rate was at highest level in the same time as Co, PBDEs and OCPs plasma concentrations during spring. We therefore identify a seasonality of the damage measured thanks to the MN rate. Similar seasonality of MN rate that parallels the variation of contaminants levels in natural environment has already been reported in fish (Costa et al. 2011; D’Costa et al. 2017; Deutschmann et al. 2016; Hussain et al. 2018; Lee and Steinert 2003; Monserrat et al. 2007). PCA on 25 selected individuals has highlighted the correlation between $\mathrm{MN}$ and the E2/11KT ratio. E2/11KT ratio correlation to the sex was found in two sturgeon species: Lake sturgeon, A. fulvescens (Cuisset 1993), and stellate sturgeon A. stellatus (Ceapa et al. 2002). We can thus suppose that the MN rate is correlated to the sex in sturgeon individuals, maybe with higher rate in females. Such higher MN rates in females have been demonstrated in mice peripheral blood cells (Heuser et al. 2008). Further analyses are needed to verify the hypothesis of a possible higher MN rate in female A.sturio.

\section{Gene transcription in blood cells}

It is not usual to measure the level of gene expression in blood cells, a prerequisite being that red blood cells are nucleated in fish. Until now, the blood cells were usually not studied in environmental toxicology, since not considered as potentially impacted by contamination. We used the blood as non-invasive sampling to obtain indications on the level of gene expression in wild sturgeons. We thus have demonstrated for the first time in a sturgeon species, the transcription in blood cells of gene encoding sexual parameter like sox 9 , known to take part to the sexual differentiation, or hormonal receptor for pituitary LH $(L H R)$, or receptors for steroid hormones $A R$ and $E R$. This is surprising because it is not thought that blood cells may need to express genes of sexual determinism or hormone receptors. It has already been shown that blood cells have the enzymatic engineering necessary for the synthesis of sex steroid hormones in rainbow trout (Schulz et al, 1992) and in Siberian sturgeon (Cuisset 1993; Cuisset et al. 1995). The meaning of such an activity is poorly documented and still not understood. The interest in the metabolic activity of red blood cells has recently increased, aimed at use blood cells as new tool for aquatic sentinel biomarker development (Maceda-Veiga et al. 2015 ; Valton et al. 2017).

Among the 25 selected fish, a tight correlation exists between transcription of reproduction-linked genes in blood cells and plasma organic contaminant, PCBs and OCPs (Table 2). This might suggest a cause and effect relationship, that is however not coherent with the hormonal assays whose levels remain quite low, suggesting that the fish do not seem to have undergone endocrine disruption. The juvenile fish concerned by these analyses had maybe not been exposed for a time long enough to develop molecular responses usually classified as endocrine disruption.

Other genes expression levels like these of sodCu and bax were also strongly correlated to PCBs and OCPs concentrations. This results indicated that reactive oxygen species had increased and that apoptotic mechanisms occurred in blood cells of sturgeons. This finding was in agreement with known effects of organic compounds like PCBs. Indeed, increased expression levels of genes involved in response to oxidative stress and apoptosis have been reported in larvae of rare minnow (Gobiocypris rarus) after exposure to Arochlor 1254 (Wu et al. 2014). In the same way, oxidative stress and apoptosis appeared in lymphocytes of Carassius auratus after in vitro exposure to PCB153 and PCB169 (Zhang et al. 2009). 


\section{Interest of non-invasive markers for monitoring the health and maturity status of endangered species}

For the first time, blood samplings were performed on European sturgeon from the natural environment. The interest of such non-invasive tissue sampling is great considering numerous data and information collected. The blood samples provided a wealth of information on the degree of contamination of estuarine part of the sturgeon population, in addition to many information on physiological parameters. Inorganic and organic contaminants, genome integrity, gene transcription, immunity and reproduction could be investigated on this species and sometimes correlated together thanks to these blood samples. In fish, blood has not generally been considered as a tissue like the others, and as such has only rarely been included in research aiming at identify responses to contaminations. The blood is at most considered a carrier fluid, for gas or nutrient as well as for hormone transport, disregarding cellular elements, and the ignorance about the proper metabolism of blood cells is almost total. Some examples are available on rainbow trout (Schulz 1986) or Siberian sturgeon blood cells (Cuisset et al. 1995). Their metabolism in response to contamination, or to stress of any sources has rarely been considered. The numerous data obtained and presented here should therefore highlight the growing interest in considering and using blood in environmental toxicology, and blood sampling on endangered species, as a non-invasive method that can provide a lot of informative data including chemical contamination and physiological status of individuals. 


\section{References}

Acolas ML, Castelnaud G, Lepage M, Rochard E (2011) Chapter 10: Biological cycle and migrations. In: Williot P, Rochard E, Desse-Berset N, Kirschbaum F, Gessner J (eds) Biology and conservation of the Atlantic European sturgeon Acipenser sturio L., 1758. Springer Berlin Heidelberg, pp 147-152

Acolas ML, Roqueplo C, Rouleau E, Rochard E (2011) Chapter 29 Post release monitoring techniques. In: Williot P, Rochard E, Desse-Berset N, Kirschbaum F, Gessner J (eds) Biology and conservation of the Atlantic European sturgeon Acipenser sturio L., 1758. Springer, Berlin Heidelberg, pp 407-416

Acolas ML, Rochard E, Le Pichon C \& Rouleau E (2012) Downstream migration patterns of one-year-old hatcheryreared European sturgeon (Acipenser sturio). Journal of Experimental Marine Biology and Ecology, 430431: 68-77

Acolas ML, Le Pichon C, Rochard, E (2017) Spring habitat use by stocked one year old European sturgeon Acipenser sturio in the freshwater-oligohaline area of the Gironde estuary. Estuarine Coastal and Shelf Science, 196: 58-69

Acolas ML, Gardes C, Adam G, Rochard E (2018) Synthesis of escapements of farmed Siberian sturgeon in French catchments: some extreme events and a lot of punctual incidents. In: Williot P, Nonnotte G, Cantonnet V, Chebanov M (eds) The Siberian Sturgeon (Acipenser baerii, Brandt, 1869) Volume 2 - Farming. Springer,

Acolas ML, Le Barh R, Lambert P, Roques S, Gazeau C, Jatteau P, Chèvre P, Jacobs L, Gesset C, Lauronce V, Rochard E (in prep) Demographic assessment of a critically endangered sustained population : first evaluation of the stocking practice for European sturgeon (Acipenser sturio)

Akcha F, Vincent Hubert F, Pfhol-Leszkowicz A (2003) Potential value of the comet assay and DNA adduct measurement in dab (Limanda limanda) for assessment of in situ exposure to genotoxic compounds Mutat Res Genet Toxicol Environ Mutagen 534(1-2):21-32

Akcha F, Leday G, Pfohl-Leszkowicz A (2004) Measurement of DNA adducts and strand breaks in dab (Limanda limanda) collected in the field: Effects of biotic (age, sex) and abiotic (sampling site and period) factors on the extent of DNA damage Mutat Res Genet Toxicol Environ Mutagen 552(1-2):197-207

Araldi RP, de Melo, TC, Mendes TB, de Sá Júnior PL, Nozima BHN, Ito ET, de Carvalho RF, de Souza EB, de Cassia Stocco R (2015) Using the comet and micronucleus assays for genotoxicity studies: A review. Biomed. Pharmacother. 72: 74-82. https://doi.org/10.1016/j.biopha.2015.04.004

Baillon L, Pierron F, Oses J, Pannetier P, Normandeau E, Couture P, Labadie P, Budzinski H, Lambert P, Bernatchez L, Baudrimont M (2016) Detecting the exposure to $\mathrm{Cd}$ and PCBs by means of a non-invasive transcriptomic approach in laboratory and wild contaminated European eels (Anguilla anguilla). Environ Sci Pollut Res 23:5431-5441 https://doi.org/10.1007/s11356-015-5754-2

Bhilwade HN, Jayakumar S, Chaubey RC (2014) Age-dependent changes in spontaneous frequency of micronucleated erythrocytes in bone marrow and DNA damage in peripheral blood of Swiss mice. Mutat. Res. Toxicol. Environ. Mutagen. $770:$ 80-84. https://doi.org/10.1016/j.mrgentox.2014.04.026

Bickham JW, Rowe GT, Palatnikov G, Mekhtiev A, Mekhtiev M, Kasimov RY, Hauschultz DW, Wickliffe JK, RogersWJ (1998) Acute and Genotoxic Effects of Baku Harbor Sediment on Russian Sturgeon, Acipenser guildenstaedti. Bull. Environ. Contam. Toxicol. 61: 512-518. https://doi.org/10.1007/s001289900792

Billard R, Lecointre G (2001) Biology and conservation of sturgeon and paddlefish Rev Fish Biol Fisheries 10:355392

Bodin N, Tapie N, Le Ménach K, Chassot E, Elie P, Rochard E, Budzinski H (2014) PCB contamination in fish community from the Gironde Estuary (France): Blast from the past. Chemosphere 98:66-72. https://doi.org/10.1016/j.chemosphere.2013.10.003

Braham RP, Blazer VS, Shaw CH, Mazik P (2017) Micronuclei and Other Erythrocyte Nuclear Abnormalities in Fishes from the Great Lakes Basin, USA Environ. Mol Mutagen 58:570-581 https://doi.org/10.1002/em.22123

Brosse L (2003) Caractérisation des habitats des juvéniles d'esturgeon européen, Acipenser sturio, dans l'estuaire de la Gironde. Ph.D thesis Université Paul Sabatié (in French)

Buckler J (2011) Thesis: Persistent organic pollutant effects on middle Mississippi river Scaphirhynchus sturgeon reproduction and early life stages. $164 \mathrm{p}$. University of Missouri-Columbia.

Budzinski H, Jones I, Bellocq J, Pierard C, Garrigues P (1997) Evaluation of sediment contamination by polycyclic aromatic hydrocarbons in the Gironde estuary. Mar Chem 58:85-97. https://doi.org/10.1016/s03044203(97)00028-5 
Castelnaud G, Rochard E, Jatteau P, Lepage M (Rochard Eric) Données actuelles sur la biologie d'Acipenser sturio dans l'estuaire de la Gironde. In: Williot P (ed) Acipenser, Bordeaux, 1991. pp 251-275

Castelnaud G (2011) Chapter 13: Sturgeon fishing, landings and caviar production during the twentieth century in the Garonne basin and the coastal sea. In: Williot P, Rochard E, Desse-Berset N, Kirschbaum F, Gessner J (eds) Biology and conservation of the Atlantic European sturgeon Acipenser sturio L., 1758. Springer Berlin Heidelberg, pp 177-194

Ceapa C, Williot P, Le Menn F, Davail-Cuisset B (2002) Preliminary data related to plasma sex steroids and vitellogenin levels in stellate sturgeon (Acipenser stellatus) during the reproduction migration in the lower Danube. Journal of Applied Ichthyology, 18: 391-396.

Cuisset B (1993) Etude endocrinologique de la fonction de reproduction chez l'esturgeon sibérien Acipenser baeri : application au sexage des populations sauvages ou élevées en pisciculture. Ph.D thesis $\mathrm{N}^{\circ} 1029$, Bordeaux University, in French

Cuisset B, Pradelles P, Kime DE, Kühn ER, Babin P, Davail S, Le Menn F (1994) Enzyme immunoassay for 11 ketotestosterone using acetyl-cholinesterase as label : application to sex identification in farm Siberian sturgeon. Comp. Biochem. Physiol., 108 C, 2, pp 229-241.

Cuisset B, Fostier A, Williot P, Bennetau-Pélissero C, Le Menn F (1995) Occurence and in vitro biosynthesis of 11ketotestosterone in Siberian sturgeon Acipenser baeri B. maturing females. Fish Physiol. Biochem., 14 (4), pp 313-322.

Costa PM, Neuparth TS, Caeiro S, Lobo J, Martins M, Ferreira AM, Caetano M, Vale C, Ángel DelValls T, Costa MH (2011) Assessment of the genotoxic potential of contaminated estuarine sediments in fish peripheral blood: Laboratory versus in situ studies. Environ. Res. 111: 25-36. https://doi.org/10.1016/j.envres.2010.09.011

Davail-Cuisset B, Lacomme S, Pelard M, Rouault T, Lepage M, Williot P (2005) Hormonal profile and vitellogenin in critically endangered sturgeon, Acipenser sturio, adapted to hatchery conditions. $5^{\text {th }}$ Int. Symp. Sturgeon, Ramsar, IRAN

Davail-Cuisset B, Lacomme S, Vianne E, Rouault T, Lepage M, Williot P (2008) Hormonal profile in adult European sturgeon, Acipenser sturio, adapted to hatchery conditions in France. Cybium 32, (2), 169-170

Davail-Cuisset B, Rouault T, Williot P (2011) Estradiol, Testosterone, 11Keto-testosterone, 17,20ß-Dihydroxy-4Pregnen-3-one and vitellogenin levels in females of captive European Atlantic sturgeon, Acipenser Sturio. Journal of Applied Ichthyology, 27 (2): 666-672

D'Costa A, Shyama SK, Praveen Kumar MK (2017) Bioaccumulation of trace metals and total petroleum and genotoxicity responses in an edible fish population as indicators of marine pollution. Ecotoxicol. Environ. Saf. 142: 22-28. https://doi.org/10.1016/j.ecoenv.2017.03.049

Deutschmann B, Kolarevic S, Brack W, Kaisarevic S, Kostic J, Kracun-Kolarevic M, Liska I, Paunovic M, Seiler TB, Shao Y, Sipos S, Slobodnik J, Teodorovic I, Vukovic-Gacic B, Hollert H (2016) Longitudinal profile of the genotoxic potential of the River Danube on erythrocytes of wild common bleak ( Alburnus alburnus ) assessed using the comet and micronucleus assay. Sci. Total Environ. 573: 1441-1449. https://doi.org/10.1016/j.scitotenv.2016.07.175

Deycard VN, Schäfer J, Petit JCJ, Coynel A, Lanceleur L, Dutruch L, Bossy C, Ventura A, Blanc G (2017) Inputs, dynamics and potential impacts of silver (Ag) from urban wastewater to a highly turbid estuary (SW France) Chemosphere 167:501-511. https://doi.org/10.1016/j.chemosphere.2016.09.154

Durrieu G, Maury-Brachet R, Girardin M, Rochard E, Boudou A (2005) Contamination by heavy metals (Cd, Zn, Cu, and $\mathrm{Hg}$ ) of eight fish species in the Gironde estuary (France) Estuaries 28:581-591 https://doi.org/10.1007/bf02696069

Farkas J, Salaberria I, Styrishave B, Stankova R, Ciesielski TM, Olsen AJ, Posch W, Flaten TP, Krokje A, Salvenmoser W, Jenssen BM (2017) Exposure of juvenile turbot (Scophthalmus maximus) to silver nanoparticles and 17 alpha-ethinylestradiol mixtures: Implications for contaminant uptake and plasma steroid hormone levels. Environ Pollut 220:328-336. https://doi.org/10.1016/j.envpol.2016.09.067

Feist GW, Webb MAH, Gundersen DT, Foster EP, Schreck CB, Maule AG, Fitzpatrick MS (2005) Evidence of detrimental effects of environmental contaminants on growth and reproductive physiology of white sturgeon in impounded areas of the Columbia River. Environ. Health Perspect 113:1675-1682. https://doi.org/10.1289/ehp.8072

Foster EP, Fitzpatrick MS, Feist GW, Schreck CB, Yates J, Spitsbergen JM, Heidel JR (2001) Plasma androgen correlation, EROD induction, reduced, condition factor, and the occurrence of organochlorine pollutants in reproductively immature white sturgeon (Acipenser transmontanus) from the Columbia River, USA Arch Environ Contam Toxicol 41:182-191 
Frenzilli G, Nigro M, Lyons B-P (2009) The Comet assay for the evaluation of genotoxic impact in aquatic environments. Mutat Res Rev Mutat Res 681(1):80-92

Goulle J-P, Mahieu L, Castermant J, Neveu N, Bonneau L, Laine G, Bouige D, Lacroix C. (2005) Metal and metalloid multi-elementary ICP-MS validation in whole blood, plasma, urine and hair. Reference values. Forensic Sci Int. 153: 39-44

Greenfield B-K, Davis J-A, Fairey R, Roberts C, Crane D-B, Ichikawa G, Petreas M (2003) Contaminant concentrations in fish from San Francisco Bay, 2000 RMP Technical Report: SFEI Contribution 77 San Francisco Estuary Institute, Oakland, CA

Grousset FE, Jouanneau JM, Castaing P, Lavaux G, Latouche C (1999) A 70 year record of contamination from industrial activity along the Garonne River and its tributaries (SW France) Estuarine. Coastal and Shelf Science 48:401-414 https://doi.org/10.1006/ecss.1998.0435

Gundersen DT, Webb MAH, Fink AK, Kushner LR, Feist GW, Fitzpatrick MS, Foster EP, Schreck CB (2008) Using blood plasma for monitoring organochlorine contaminants in juvenile white sturgeon, Acipenser transmontanus, from the lower Columbia River. Bulletin of Environmental Contamination and Toxicology 81:225-229. https://doi.org/10.1007/s00128-008-9417-6

Hariri M, Mirvaghefi A, Farahmand H, Taghavi L, Shahabinia AR (2018) In situ assessment of Karaj River genotoxic impact with the alkaline comet assay and micronucleus test, on feral brown trout (Salmo trutta fario) Environ Toxicol Pharmacol 58:59-69. https://doi.org/10.1016/j.etap.2017.12.024

Hartmann A, Agurell E, Beevers C, Brendler-Schwaab S, Burlinson B, Clay P, Collins A, Smith A, Speit G, Thybaud V, Tice R-R (2003) Recommendations for conducting the in vivo alkaline Comet assay. Mutagenesis 18:4551

Heuser VD, Andrade VMD, Peres A, Braga LMGM de, Chies JAB (2008) Influence of age and sex on the spontaneous DNA damage detected by Micronucleus test and Comet assay in mice peripheral blood cells. Cell Biol. Int. 32: 1223-1229. https://doi.org/10.1016/j.cellbi.2008.07.005

Hosseini SV, Behrooz RD, Esmaili-Sari A, Bahramifar N, Hosseini SM, Tahergorabi R, Hosseini SF, Feás X (2008) Contamination by organochlorine compounds in the edible tissue of four sturgeon species from the Caspian Sea (Iran) Chemosphere 73: 972- 979. https://doi.org/10.1016/j.chemosphere.2008.06.036

Hussain B, Sultana T, Sultana S, Ahmed Z, Mahboob S (2018) Fish eco-genotoxicology: Comet and micronucleus assay in fish erythrocytes as in situ biomarker of freshwater pollution. Saudi J Biol Sci 25(2):393-398. https://doi.org/10.1016/j.sjbs.2017.11.048

Jacobs GR, Gundersen DT, Webb MAH, Gorsky D, Kohl K, Lockwood K (2014) Evaluation of Organochlorine Pesticides and Sex Steroids in Lower Niagara River Lake Sturgeon. J Fish Wildl Manag 5:109-117 https://doi.org/10.3996/072013-jfwm-048

Kajiwara N, Ueno D, Monirith I, Tanabe S, Pourkazemi M, Aubrey DG (2003). Contamination by organochlorine compounds in sturgeons from Caspian Sea during 2001 and 2002. Mar. Pollut. Bull. 46: 741-747. https://doi.org/10.1016/S0025-326X(03)00047-X

Kraepiel AML, Chiffoleau JF, Martin JM, Morel FMM (1997) Geochemistry of trace metals in the Gironde estuary Geochim Cosmochim Acta 61:1421-1436. https://doi.org/10.1016/s0016-7037(97)00016-1

Lagadic T, Caquet JC, Amiard C, Ramade F (1997) Biomarqueurs en écotoxicologie, aspects fondamentaux. Masson, Paris.

Lanceleur L, Schäfer J, Chiffoleau JF, Blanc G, Auger D, Renault S, Baudrimont M, Audry S (2011) Long-term records of cadmium and silver contamination in sediments and oysters from the Gironde fluvial-estuarine continuum Evidence of changing silver sources. Chemosphere 85:1299-1305. https://doi.org/10.1016/j.chemosphere.2011.07.036

Lanceleur L, Schäfer J, Blanc G, Coynel A, Bossy C, Baudrimont M, Glé C, Larrose A, Renault S, Strady E (2013) Silver behaviour along the salinity gradient of the Gironde Estuary. Environ Sci Pollut Res 20:1352-1366 https://doi.org/10.1007/s11356-012-1045-3

Lauzent M. (2017) Etude de l'écodynamique des polluants organiques persistants et des micropolluants halogénés d'intérêt émergent dans les milieux aquatiques. Ph.D thesis Université de Bordeaux, 390 p. (in French)

Lee RF, Steinert S (2003) Use of the single cell gel electrophoresis/comet assay for detecting DNA damage in aquatic (marine and freshwater) animals. Mutat. Res. Mutat. Res. 54: 43-64. https://doi.org/10.1016/S13835742(03)00017-6

Li H, Drouillard KG, Bennett E, Haffner GD, Letcher RJ (2003) Plasma-associated halogenated phenolic contaminants in benthic and pelagic fish species from the Detroit River. Environmental Science and Technology 37:832839 
Livak KJ, Schmittgen TD (2001) Analysis of relative gene expression data using real-time quantitative PCR and the 2- $\Delta \Delta$ CT method. Methods 25, 402-408. https://doi.org/10.1006/meth.2001.1262

Lobry J, Mourand L, Rochard E, Elie P (2003) Structure of the Gironde estuarine fish assemblages: a comparison of European estuaries perspective. Aquat Living Resour 16:47-58. https://doi.org/10.1016/s0990$\underline{7440(03) 00031-7}$

Luna-Acosta A, Budzinski H, Le Menach K, Thomas-Guyon H, Bustamante P (2015) Persistent organic pollutants in a marine bivalve on the Marennes-Oléron Bay and the Gironde Estuary (French Atlantic Coast)-Part 1: Bioaccumulation. Sci. Total Environ. 514: 500-510

MacDonald DD, Ikonomou MG, Rantalaine AL, Rogers IH, Sutherland D, Van Oostdam J (1997) Contaminants in white sturgeon (Acipenser transmontanus) from the upper Fraser River, British Columbia, Canada Environ.

Toxicol. Chem. 16: 479-490.

Maceda-Veiga A, Figuerola J, Martínez-Silvestre A, Viscor G, Ferrari N, Pacheco M (2015) Inside the Redbox: Applications of haematology in wildlife monitoring and ecosystem health assessment. Sci. Total Environ. 514: 322-332. https://doi.org/10.1016/j.scitotenv.2015.02.004

Maury-Brachet R, Rochard E, Durrieu G, Boudou A (2007) The 'Storm of the Century' (December 1999) and the accidental escape of Siberian sturgeons (Acipenser baeri) into the Gironde estuary (Southwest France) Environ Sci Pollut Res 15:89. https://doi.org/10.1065/espr2007.12.469

Masson M, Blanc G, Schäfer J (2006) Geochemical signals and source contributions to heavy metal $(\mathrm{Cd}, \mathrm{Zn}, \mathrm{Pb}, \mathrm{Cu})$ fluxes into the Gironde Estuary via its major tributaries. Sci Total Envir 370:133-146 https://doi.org/10.1016/j.scitotenv.2006.06.011

Ministère de l'écologie du développement durable des transports et du logement (2011) Plan national d'actions en faveur de l'esturgeon européen Acipenser sturio 2011-2015.

Mitchelmore CL, Chipman JK (1998) DNA strand breakage in aquatic organisms and the potential value of the comet assay in environmental monitoring. Mutat Res Fund Mol Mech Mutagen 399(2):135-147

Monserrat JM, Martínez PE, Geracitano LA, Lund Amado L, Martinez Gaspar Martins C, Lopes Leães Pinho G, Soares Chaves I, Ferreira-Cravo M, Ventura-Lima J, Bianchini A (2007) Pollution biomarkers in estuarine animals: Critical review and new perspectives. Comp. Biochem. Physiol. Part C Toxicol. Pharmacol. 146: 221-234. https://doi.org/10.1016/j.cbpc.2006.08.012

Nash JP, Cuisset-Davail B, Bhattacharya S, Suter HC, Le Menn F, Kime DE (2000) An enzyme linked immunosorbant assay (E.L.I.S.A.) for testosterone, estradiol, and 17,20ß-dihydroxy-4-pregnene-3-one using acetylcholinesterase as tracer : application to measurement of diel patterns in rainbow trout (Oncorhynchus mykiss). Fish Physiol. Biochem., 22: 355-363

Olive PL, Banath JP (1995) Sizing Highly Fragmented DNA in Individual Apoptotic Cells Using the Comet Assay and a DNA Crosslinking Agent. Exp Cell Res 221:19-26

Polard T, Jean S, Merlina G, Laplanche C, Pinelli E and Gauthier L (2011) Giemsa versus acridine orange staining in the fish micronucleus assay and validation for use in water quality monitoring. Ecotoxicol Environ Saf. 74:144-149

Rochard E, Lepage M, Dumont P, Tremblay S, Gazeau C (2001) Downstream migration of juvenile European sturgeon Acipenser sturio L. in the Gironde Estuary. Estuaries 24:108-115

Rosenthal H, Bronzi P, Gessner J, Moreau D, Rochard E, Lasen C (2007) Draft action plan for the conservation and restoration of the European sturgeon (Acipenser sturio). Council of Europe, Convention on the conservation of European wildlife and natural habitats, Strasbourg

Schulz R (1986) In vitro metabolism of steroid hormones in the liver and blood cells of male rainbow trout (Salmo gairdneri, Richardson) Gen. Comp. Endocrinol. 64:312-319

Singh NP, Mc Coy MT, Tice RR, Schneider EL (1988) A simple technique for quantitation of low levels of DNA damage in individual cells. Exp. Cell Res. 175: 184-191

Sturrock AM, Hunter E, Milton JA, Trueman CN (2013) Analysis methods and reference concentrations of 12 minor and trace elements in fish blood plasma $J$ Trace Elem Med Biol 27:273-285. https://doi.org/10.1016/j.jtemb.2013.03.001

Tapie N, Le Menach K, Pasquaud S, Elie P, Devier MH, Budzinski H (2011) PBDE and PCB contamination of eels from the Gironde estuary: From glass eels to silver eels. Chemosphere 83:175-185 https://doi.org/ 10.1016/j.chemosphere.2010.12.044

Tartu S, Angelier F, Bustnes JO, Moe B, Hanssen SA, Herzke D, Gabrielsen GW, Verboven N, Verreault J, Labadie P, Budzinski H, Wingfield JC, Chastel O (2015) Polychlorinated biphenyl exposure and corticosterone levels in seven polar seabird species. Environmental Pollution 197: 173-180 
Toft JD, Munsch SH, Cordell JR, Siitari K, Hare VC, Holycross BM, DeBruyckere LA, Greene CM, Hughes BB (2018) Impact of multiple stressors on juvenile fish in estuaries of the northeast Pacific Global Change Biology 24:2008-2020 https://doi.org/10.1111/gcb.14055

Valters K, Li H, Alaee M, D’Sa I, Marsh G, Bergman Å, Letcher R-J (2005) Polybrominated diphenyl ethers and hydroxylated and methoxylated brominated and chlorinated analogues in the plasma of fish from the Detroit

River. Environ. Sci. Technol. 39: 5612-5619. https://doi.org/10.1021/es0506410

Valton E, Wawrzyniak I, Amblard C, Combourieu B, Bayle ML, Desmolles F, Kwiatkowski F, Penault-Llorca F, Bamdad M (2017) P-gp expression levels in the erythrocytes of brown trout: a new tool for aquatic sentinel biomarker development. Biomarkers 22(6): 566-574

Van der Oost R, Beyer J, Vermeulen NPE (2003) Fish bioaccumulation and biomarkers in environmental risk assessment: a review. Environmental Toxicology and Pharmacology 13, 57-149.

Williot P, Rouault T, Pelard M, Mercier D, Lepage M, Davail-Cuisset B, Kirschbaum F, Ludwig A (2007) Building a broodstock of the critically endangered sturgeon Acipenser sturio: problems and observations associated with the adaptation of wild-caught fish to hatchery conditions. Cybium 31:3-11

Wu F, Zheng Y, Gao J, Chen S, Wang Z (2014) Induction of oxidative stress and the transcription of genes related to apoptosis in rare minnow (Gobiocypris rarus) larvae with Aroclor 1254 exposure. Ecotoxicol Environ Saf. 110:254-60. https://doi.org/10.1016/j.ecoenv.2014.09.012

Zhang K., Wan Y, Giesy JP, Lam MHW, Wiseman S, Jones PD, Hu J (2010) Tissue concentrations of polybrominated compounds in Chinese sturgeon (Acipenser sinensis): Origin, hepatic sequestration, and maternal transfer. Environ. Sci. Technol. 44: 5781-5786. https://doi.org/10.1021/es100348g

Zhang J, Zhang H, Ni W (2009) Oxidative stress and apoptosis of Carassius auratus lymphocytes induced by nonplanar (PCB153) and coplanar (PCB169) polychlorinated biphenyl congeners in vitro. J Environ Sci (China). 21:1284-1289. 